Life Sciences Contribution

Royal Ontario Museum

101

Redescription of Type Specimens of the Bryozoan Heterotrypa from Upper Ordovician Rocks of the Credit River Valley, Ontario, Canada

Madeleine A. Fritz

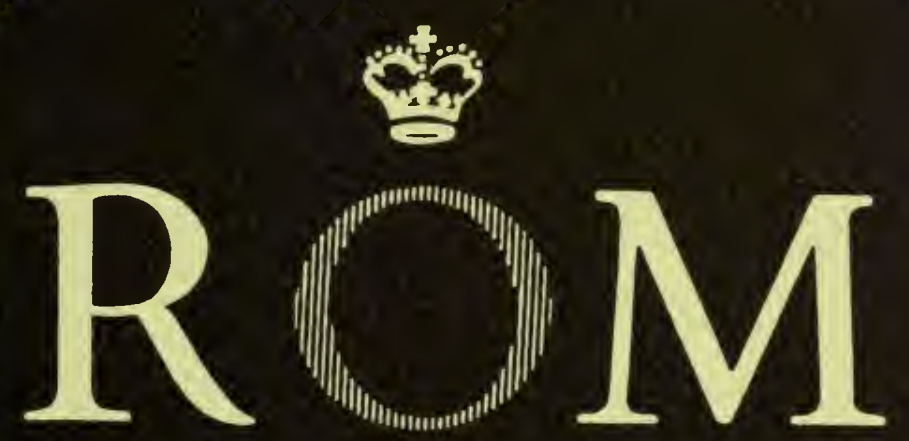


Digitized by the Internet Archive in 2011 with funding from University of Toronto 
LIFE SCIENCES CONTRIBUTIONS

ROYAL ONTARIO MUSEUM

NUMBER 101

madeleine a. fritz Redescription of Type Specimens of the Bryozoan Heterotrypa from Upper Ordovician Rocks of the Credit River Valley, Ontario, Canada

Publication date: 25 January 1975

ISBN 0-88854-169-4

Suggested citation: Life Sci. Contr., Roy. Ont. Mus. 


\section{ROYAL ONTARIO MUSEUM \\ PUBLICATIONS IN LIFE SCIENCES}

The Royal Ontario Museum publishes three series in the Life Sciences:

LIFE SCIENCES CONTRIBUTIONS, a numbered series of original scientific publications, including monographic works.

LIFE SCIENCES OCCASIONAL PAPERS, a numbered series of original scientific publications, primarily short and usually of taxonomic significance.

LIFE SCIENCES MISCELlANEOUS PUBLICATIONS, an unnumbered series of publications of varied subject matter and format.

All manuscripts considered for publication are subject to the scrutiny and editorial policies of the Life Sciences Editorial Board, and to review by persons outside the Museum staff who are authorities in the particular field involved.

\section{LIFE SCIENCES EDITORIAL BOARD}

Chairman: WALTER M. TOVELL

Editor: J. C. BARLOW

Associate Editor: A. R. EMERY

Associate Editor: D. W. BARR

MADELEINE A. FRITZ is a Research Associate in the Department of Invertebrate Palaeontology, Royal Ontario Museum, Toronto, Ontario.

PRICE : $\$ 1.75$

(C) The Royal Ontario Museum, 1975

100 Queen's Park, Toronto, Canada

PRINTED AND BOUND IN CANADA AT THE BRYANT PRESS LIMITED 


\title{
Redescription of Type Specimens of the Bryozoan Heterotrypa from Upper Ordovician Rocks of the Credit River Valley, Ontario, Canada
}

\begin{abstract}
Dyer (1925) described three new species and two new varieties of Heterotrypa from the Upper Ordovician rocks outcropping in the valley of the Credit River some 20 miles west of Toronto, Ontario. These types, located in the Department of Invertebrate Palaeontology of the Royal Ontario Museum, are redescribed, using qualitative and quantitative analyses and improved illustrations. In addition, data for Ulrich's type of $H$. prolifica as given by Utgaard and Perry (1964) were used for comparison with Dyer's plesiotype of that species.
\end{abstract}

\section{Introduction}

The Upper Ordovician rocks that underlie Toronto and vicinity are included in the Georgian Bay Formation (Liberty, 1969). Before 1969 two formations were recognized, namely, Dundas (Parks, 1924) and Meaford (Foerste, 1924). These two formations were correlated respectively with the Maysville and Richmond of Ohio. The Meaford Formation was divided by Dyer into three members in descending order: Meadowvale, Streetsville, and Erindale.

The rich, well-preserved bryozoan fauna contained in these rocks was first described by Parks and Dyer (1922) and Dyer (1925). Armstrong (1945) restudied some of the Parks and Dyer species as part of a revision of the genus Stigmatella. Because the descriptions of these early investigators do not meet present standards, I began in 1969 a study of the type specimens designated by the above authors and located in the Department of Invertebrate Palaeontology of the Royal Ontario Museum (Fritz, 1970, 1971, 1973). The more detailed descriptions resulting from this study should serve as a basis for work in the future, when further systematic collecting will most certainly reveal species at present unknown. Furthermore, this increased knowledge of the fauna will permit closer comparison with similar assemblages known elsewhere than has hitherto been possible. 


\section{Materials and Methods}

The type specimens of the following taxa constitute the material dealt with herein:

Heterotrypa definita Dyer, 1925

Heterotrypa prolifica (Ulrich, 1890) (determined here to be H. [Atactopora] subramosa Ulrich, 1879)

Heterotrypa robusta Dyer, 1925

Heterotrypa simplex Dyer, 1925

Heterotrypa simplex maculosa Dyer, 1925 (considered here to be a new species, H. maculosa)

Heterotrypa subpulchella parvulipora Dyer, 1925 (considered here to represent a new species $H$. meafordensis Fritz, new status).

In addition, data of $H$. prolifica as given by Utgaard and Perry (1964) was used for comparison with Dyer's plesiotype of that species. The holotype of $\mathrm{H}$. microstigma Cumings and Galloway, located in Indiana University, was studied in order to determine its relationship to $H$. robusta.

The external features of the zoaria (i.e. shape of the colony, character of the surface) were observed with the aid of a hand lens, but the internal structures of each species were determined by means of thin sections. The mensuration of the number of zooecia in $2 \mathrm{~mm}$ in the intermonticular areas and measurements in millimetres of the maximum dimension of zooecial apertures in the monticular and intermonticular areas were made with the aid of a binocular microscope and a micrometer scale calibrated to $.01 \mathrm{~mm}$. The number of entire mesopores and the number of entire acanthopores in $1 \mathrm{~mm}^{2}$ were obtained by using a compound microscope and a reticle calibrated to $1 \mathrm{~mm}^{2}$. Statistical computations were made on the IBM $370 / 165$ computer at the University of Toronto Computer Centre. As most of the samples had heterogeneous variances it was not possible to test differences among means using parametric statistical methods. Instead, the samples were tested for differences in dispersion using the non-parametric Mann-Whitney U-Test (Siegel, 1956). In the tables probability ranges associated with significance tests are designated with asterisks as follows: $* * *=P \leq 0.001 ; * *=P \leq 0.01$; $*=P \leq 0.1$; not significant $=\mathrm{ns}=P>0.05$. 


\title{
Systematic Palaeontology
}

\author{
Order Trepostomata Ulrich 1882a, b \\ Family Heterotrypidae Ulrich 1890
}

\section{Genus Heterotrypa Nicholson 1879}

Through a misidentification, originally detected by Ulrich (1882a), Nicholson (1879) designated a type species for Heterotrypa that did not fit the concept of the genus as utilized by Nicholson, Ulrich (1895) and all subsequent workers. Utgaard and Boardman (1965) reviewed the nomenclatorial problem of the type species of Heterotrypa and proposed to the International Commission on Zoological Nomenclature that Monticulipora frondosa D'Orbigny, 1850 be designated the type species of the genus Heterotrypa. This proposal was approved and published as Opinion 838 (1968) of the International Commission on Zoological Nomenclature.

Nicholson's description of Heterotrypa (1881) is somewhat fuller than the original of 1879: "Corallites of two kinds, the larger ones subpolygonal, partially separated by the development of numerous smaller, circular or irregularly shaped tubes, of which there is no more than a single row between any pair of larger tubes. Walls thickened towards the mouths of the tubes, and often apparently amalgamated in this region. Spiniform corallites usually present, but sometimes wanting. Tabulae conspicuously more numerous in the smaller tubes than in the larger ones."

Boardman and Utgaard (1966) presented the following emended definition of Heterotrypa:

Zoaria are frondose, ramose, or less commonly incrusting.

In exozone, individual zooecial walls can be extremely variable in thickness, and in some species are conspicuously moniliform. In longitudinal section, the zooecial boundary is commonly a conspicuous dark line in inner exozones and a broad zone of abutting laminae or completely obscured in outer exozones. In some earlier species of the genus, zooecial boundaries are narrow and well defined throughout exozones. Wall laminae are broadly convex on either side of the boundaries and lighter colored zooecial linings are common in thicker-walled specimens. Walls generally are amalgamate in appearance and mural lacunae are prominently developed in several species.

Diaphragms are generally few in endozones, but are moderately abundant in some species. In exozones, diaphragms are commonly closely and regularly spaced, thin, planar and perpendicular to zooecial walls. Locally, diaphragms are widely or irregularly spaced, convex, or cystose.

Intermonticular mesopores range from abundant and regularly arranged in some species to scattered or essentially absent in others. Mesopores commonly develop moniliform chambers at proximal ends and tend to become smaller or are terminated distally within exozones. Mesopore diaphragms commonly are noticeably thicker and more closely spaced than zooecial diaphragms. Mesopore walls are thinner and more irregular in thickness than zooecial walls.

Acanthopores are of at least two kinds within the genus, regular acanthopores limited to exozones, and endacanthopores originating in both endozone and exozone. Exozonal acanthopores are present in most species, generally between zooecial corners, and either extend throughout the exozone or are shortened and restricted to a part of the exozone. The shortened acanthopores are commonly offset and occur in concentrated zones within a zoarium. The fully extended acanthopores can be either centered or offset.

Endacanthopores originating in endozones occur in all species. Some endacanthopores originate in inner exozones also in most species. Both types extend into exozones and generally terminate within broader exozones so that shallow tangential sections show few 
if any endacanthopores. Some endacanthopores are oblique to the axis of zooecial voids in the exozone. Endacanthopores occur in zooecial corners and are typically centered in petaloid clusters of several zooecia. They are generally larger and never smaller in diameter than exozonal acanthopores.

Monticules generally have a central cluster of a few to many mesopores surrounded by larger zooecia than those in intermonticular areas. Within monticules, acanthopores can be larger in diameter and walls thicker than those in intermonticular areas.

\section{Type Species Heterotrypa (Monticulipora) frondosa D'Orbigny 1849}

A feature not often referred to in the study of trepostomes is the granular nature of the zooecial wall laminae. Cumings and Galloway (1915) using magnifications $\times 287$ demonstrated clearly that the concentric laminae comprising the walls revealed the presence of granules which varied in size according to their particular location. The granular nature of the wall is especially well shown in sections studied in this project (Figs. 4, 5). Using the scanning electron microscope (SEM) the morphology and possible function of these granules might be revealed.

\section{Heterotrypa definita Dyer, 1925}

Figs. 1A-C, 5E-F

\section{Original Description (Dyer, 1925)}

The coarse branching zoaria of this well-defined species are found in great numbers in the bryozoan reef in the Strophomena varsensis zone of the Erindale member. The branches are large, commonly reaching $15 \mathrm{~mm}$ in diameter. Maculae, each made up of about 20 mesopores, are arranged evenly over the surface with an average distance of two millimetres between them.

In tangential sections $H$. definita resembles $H$. simplex maculosa Dyer of the Streetsville member in that the acanthopores are arranged very similarly, one to each angle of junction of the zooecial walls. It differs, however, from that species in the distribution of mesopores. In $H$. definita they are gathered into maculae as well as being distributed evenly throughout the whole zoarium, while in $H$. simplex maculosa they are found only in the maculae. In addition, the groups of mesopores are never surrounded by zooecia of larger than average size in the former as they are in the latter.

The most striking characteristic of this species is observed in the longitudinal sections. At different periods of growth of the zooecia the walls become so swollen that a long continuous line of swellings can be followed for the whole length of the section, in one instance for a distance of three millimetres. The diaphragms are comparatively numerous, an average of 10 being found in each tube, but they are entirely wanting in the axial zone. In the same manner as the swellings referred to above, the diaphragms occur at similar levels in the various zooecia, giving the appearance of continuous horizontal lines in the vertical section. In some cases the lines of diaphragms coincide with the lines of swelling, and in other cases they alternate with them.

This species has been placed in the genus Heterotrypa on account of the numerous diaphragms, thick walls, and general resemblance to undoubted members of that genus from the Credit River Section. In one feature, however, it greatly resembles Stigmatella, namely, in the possession of periodic thickenings which is considered by Ulrich and Bassler as one of the characteristics of the latter genus.

The coarse, branching surface covered with maculae, and the periodic thickening of the walls form a combination of features by which this form is easily distinguished from any other species of bryozoa. 

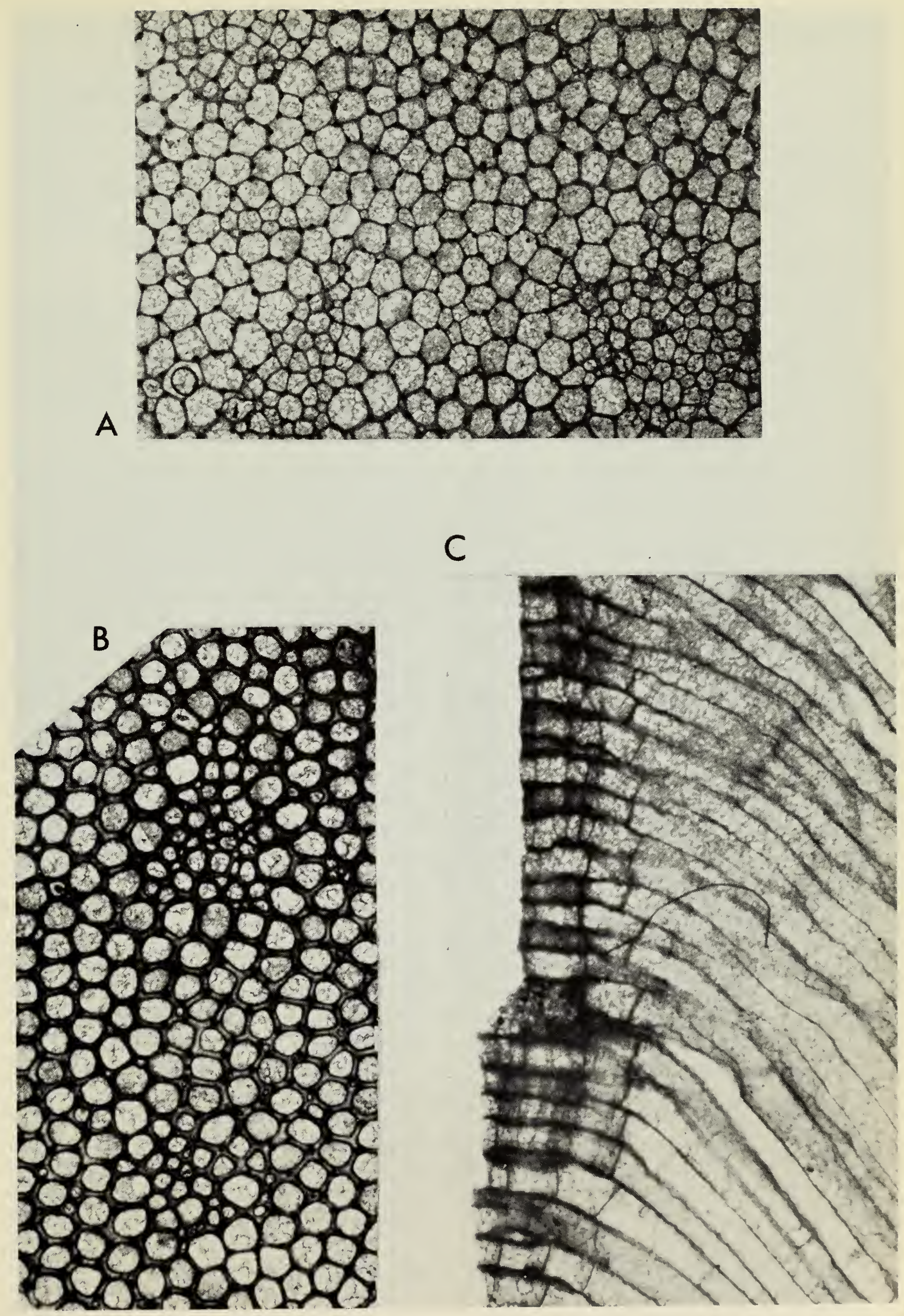

Fig. 1 A-C. Heterotrypa definita, Dyer, $\times 30$

A-B. Tangential sections (

C. Longitudinal section (ROM 12154). 


\section{Emended Description}

Dyer based his description of the microstructure of $H$. definita upon sections from syntype ROM 12155, an embedded specimen which gave no clue to the shape of the zoarium. Syntype ROM 12154, a well-preserved specimen free from the matrix, revealed the zoarial form. This specimen is herein selected as a lectotype. Dyer assumed that this specimen belonged to the same species, although he made no sections to substantiate the assumption. However, from a study of sections now available it is clear that the two are conspecific.

\section{EXTERNAL FEATURES}

Zoarium of large, round to slightly compressed branches given off dichotomously (Dyer, 1925), diameter ranging from 13 to $20 \mathrm{~mm}$; before bifurcation zoarial mass reaches width of $35 \mathrm{~mm}$. Surface with small, inconspicuous monticules, 1.5 to $2 \mathrm{~mm}$ apart measuring from centre to centre, and composed of larger zooecia than in the intermonticular areas; centre of monticules with cluster of mesopores.

\section{TANGENTIAL SECTION}

Zooecial apertures angular in deep sections where wall thin, subangular to subcircular to circular near surface where wall thickens (Fig. 1A, B), 7 to 12 entire zooecia in $2 \mathrm{~mm}$ (Table 1); thickness of zooecial walls ranges from $0.01 \mathrm{~mm}$ (or less) in deep parts of section to $0.03-0.05 \mathrm{~mm}$ in sections near surface, and up to $0.07 \mathrm{~mm}$ in monticules; wall concentrically laminated, laminae granular, at surface wall dense owing to closely packed laminae, in peripheral zone median lightcoloured ring, at greater depth light-coloured ring replaced by faint black line of demarcation. Mesopores 5-6 in $1 \mathrm{~mm}^{2}$ in intermonticular area (Table 1). Acanthopores abundant, 25-43 in $1 \mathrm{~mm}^{2}$ in intermonticular area (Table 1), seldom inflecting near surface but strongly inflecting in subsurface sections, diameter range 0.01 to $0.04 \mathrm{~mm}$, commonly 0.03 to 0.04 , situated usually at the angles of junction of adjacent zooecia and composed of dense concentric laminae with small central lumen. Monticules with larger zooecia than those in intermonticular areas and with clusters of small mesopores in centre, the clusters often exhibiting a stellate arrangement (Fig. 1A, B). Maximum diameter zooecial apertures in $\mathrm{mm}$ in monticules 0.14-0.19 (Table 1). Maximum diameter of zooecial apertures in intermonticular areas $0.09-0.13 \mathrm{~mm}$ (Table 1 ).

\section{LONGITUDINAL SECTION}

Zooecia curve broadly from axial to peripheral zone intersecting zoarial surface either at right angles or somewhat obliquely; several periods of growth represented (Fig. 1C). Walls very thin in axial zone with periodic fine crenulation, thickening greatly and becoming slightly moniliform from base of the peripheral zone; wall laminated, laminae convex outward, diverging from light-coloured central area usually at an angle of about $40-45^{\circ}$ and passing into diaphragms. Diaphragms straight or slightly oblique, virtually absent in the thin-walled axial zone, their apparent absence possibly due to destruction, numerous throughout the peripheral zone where 10 to 12 occur in a given zooecium, spaced from one-half to two tube diameters apart, the broader spacing being in the subperipheral area. Sections passing through a monticule show clearly the central cluster of small mesopores with closely spaced diaphragms. Acanthopores flanked by laminae which extend outward and diverge from central light-coloured lumen at a relatively low angle then pass into zooecia and mesopores; acanthopores often cut across trend of zooecia. 


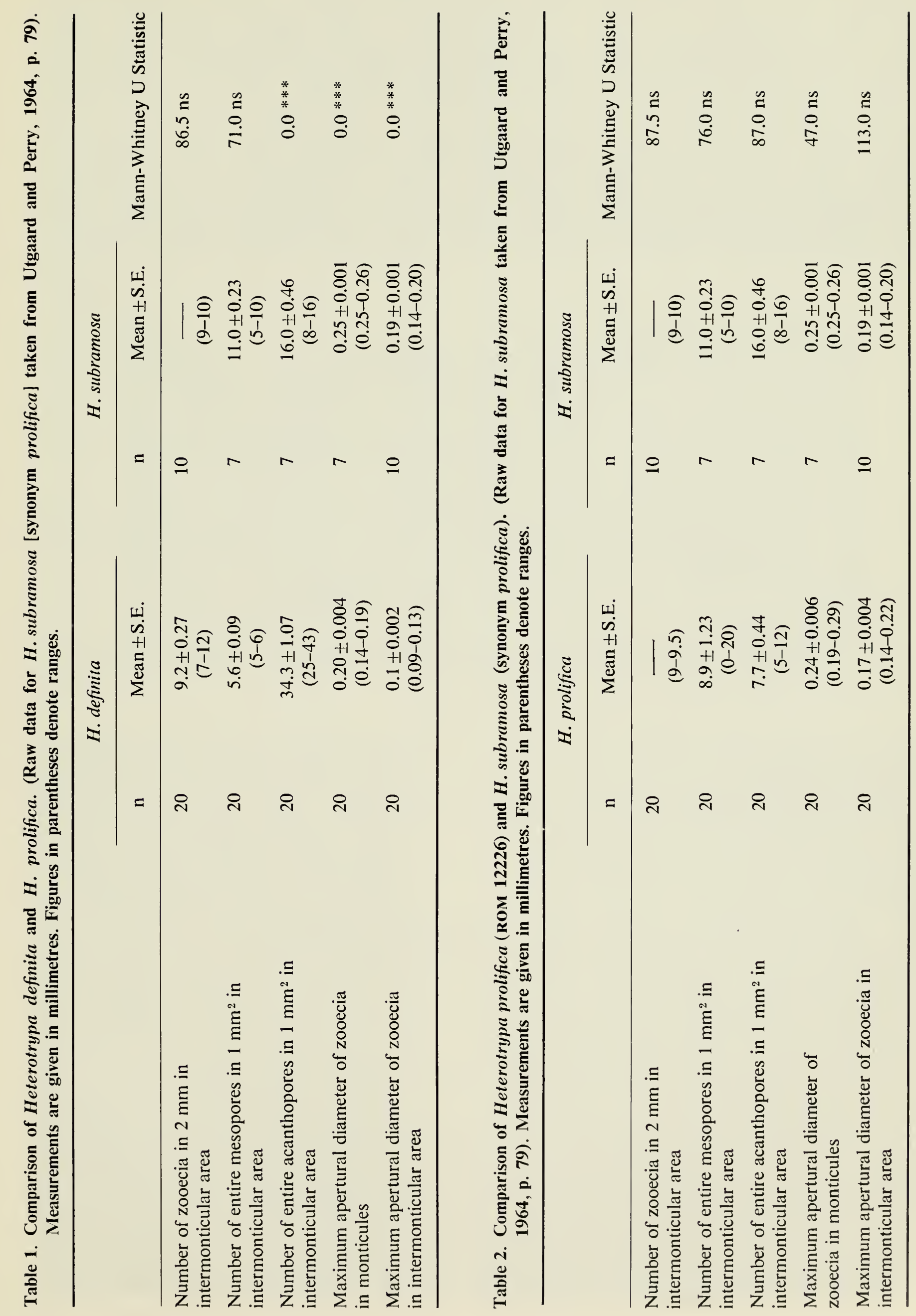




\section{Remarks}

In placing this species in the genus Heterotrypa, I agree with Dyer that the thick walls and numerous diaphragms in the peripheral zone warrant the generic designation.

Utgaard and Perry (1964), without examining Dyer's types, stated that $H$. subramosa from their Indiana-Ohio fauna, which they regard as a synonym for $H$. prolifica Ulrich, differs from $H$. definita "as the latter species lacks larger zooecia in the monticules than in the intervening areas and lacks diaphragms in the axial region". The present study has shown that diaphragms are not lacking in the axial region and that $H$. definita possesses larger zooecia in the monticules than in the intervening areas although they are smaller than in the specimens of the above authors. Furthermore, the striking central clusters of mesopores in $H$. definita, which are characteristically stellate in shape, are a distinctive feature not observed in Indiana specimens. The two species show significant quantitative differences in the number of acanthopores in $1 \mathrm{~mm}^{2}$, in the apertural diameter of zooecia in $\mathrm{mm}$ in the monticular area, and in the apertural diameter of zooecia in the intermonticular area (Table 1). My conclusion, therefore, is that $H$. definita and $H$. subramosa are significantly different.

Among the associated Credit species, $H$. definita and $H$. robusta are stout, ramose forms that might be confused. See $H$. robusta below for description of differences.

\section{Locality}

Meaford Formation, Upper Ordovician, Mullet Creek, Credit River, Erindale, Ontario (ROM 12154); Section 10, West Side, Credit River, north of home of William Crozier ( вом 12155).

\section{Type}

Lectotype ROM 12154; paralectotype ROM 12155.

\section{Heterotrypa prolifica (Ulrich 1890)}

Figs. 2A-B, 5C

Atactopora subramosa Ulrich, 1879

Heterotrypa prolifica Ulrich, 1890

Heterotrypa prolifica Dyer, 1925

Heterotrypa subramosa Utgaard \& Perry, 1964

Dyer (1925) referred to this species as follows: "This species occurs in the bryozoan reef in the Strophomena varsensis zone of the Erindale member. It differs from the type species in a few minor details. The acanthopores in the Credit River forms are a little larger than in the type and show a slight variation in size. There is also a greater tendency toward the grouping of mesopores in the type species. In Ohio, according to Shideler, $H$. prolifica ranges from the Lower Arnheim to the Upper Whitewater and, accordingly, is of little use for purposes of exact correlation." 


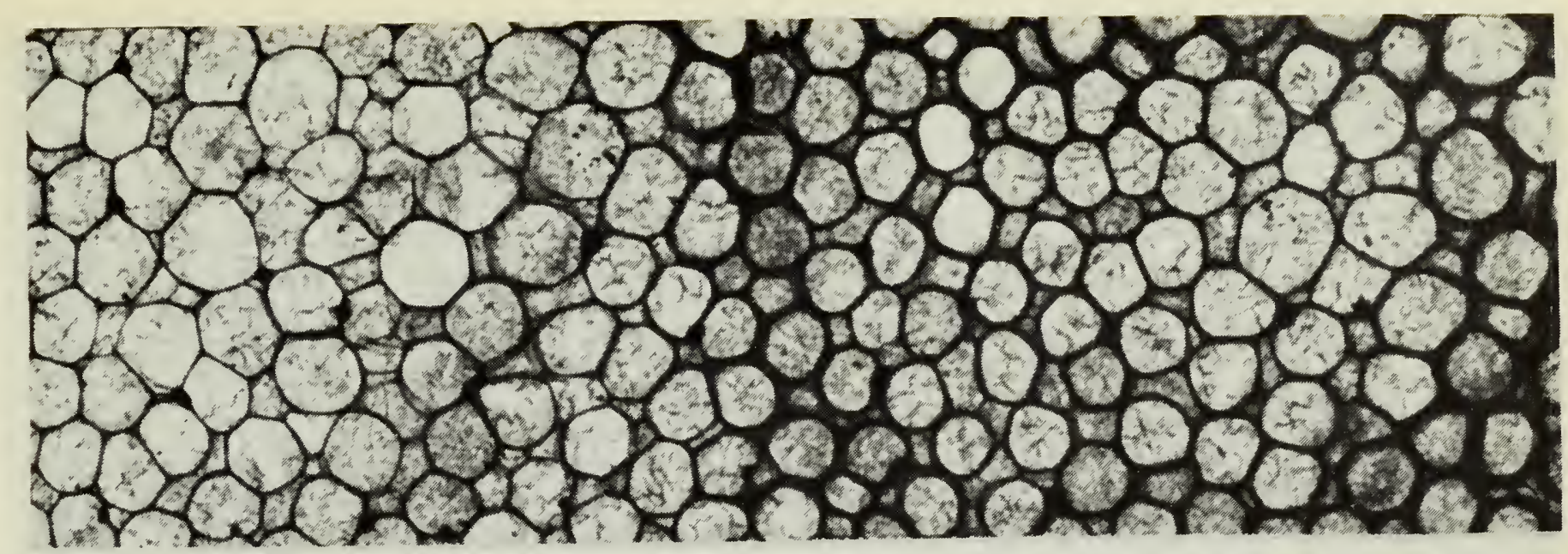

A
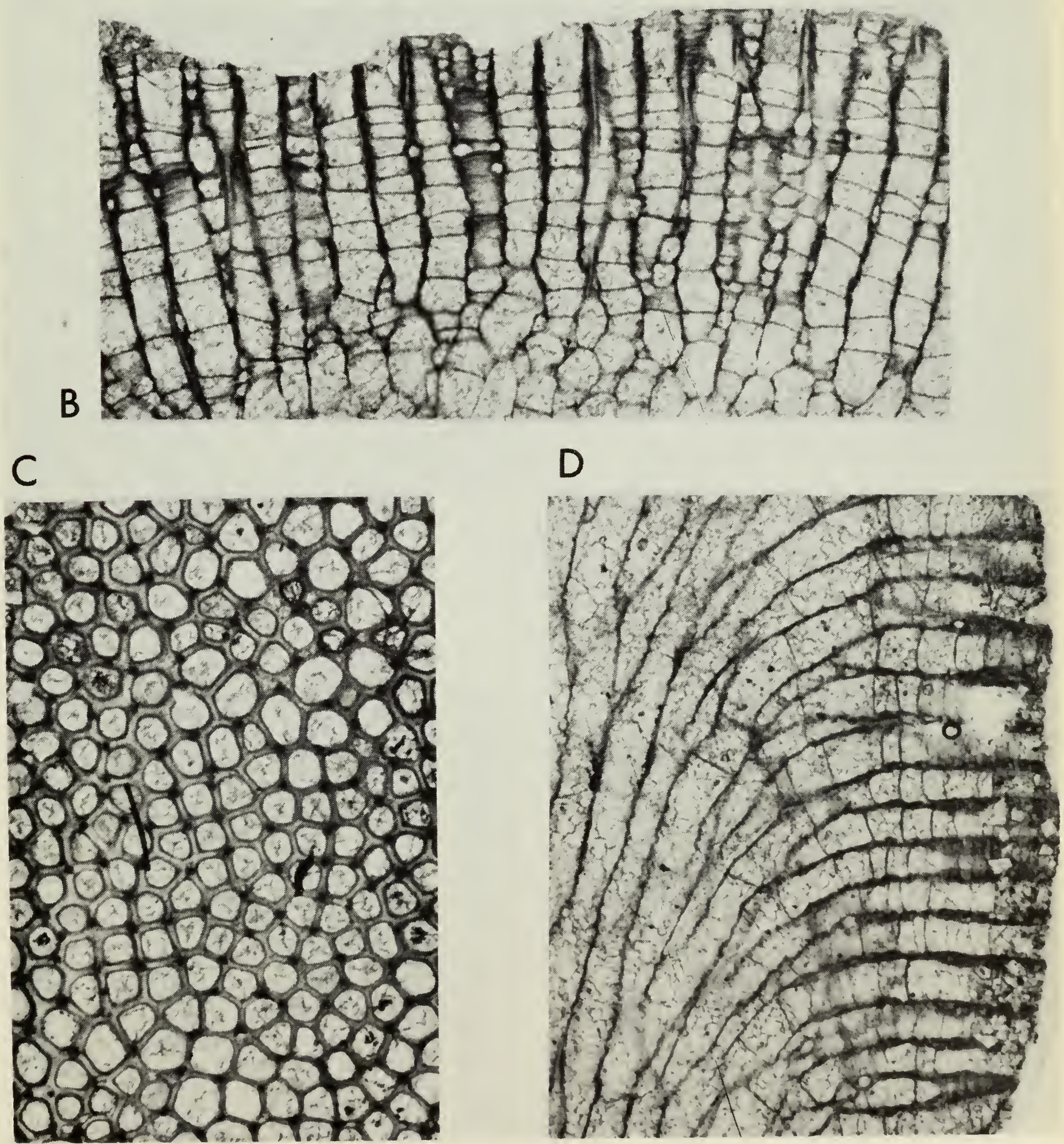

Fig. 2 A-D, $\times 30$. 


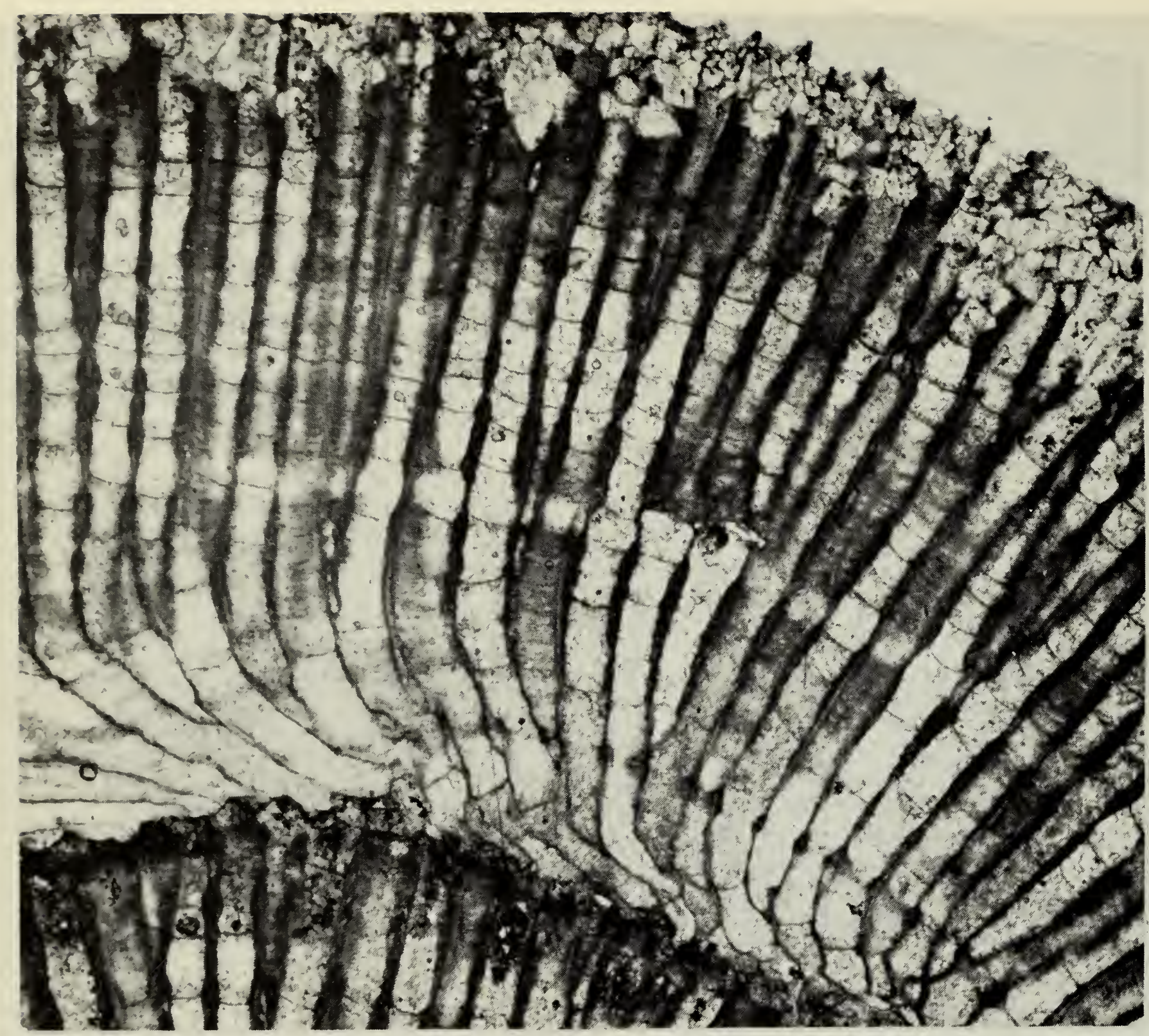

A

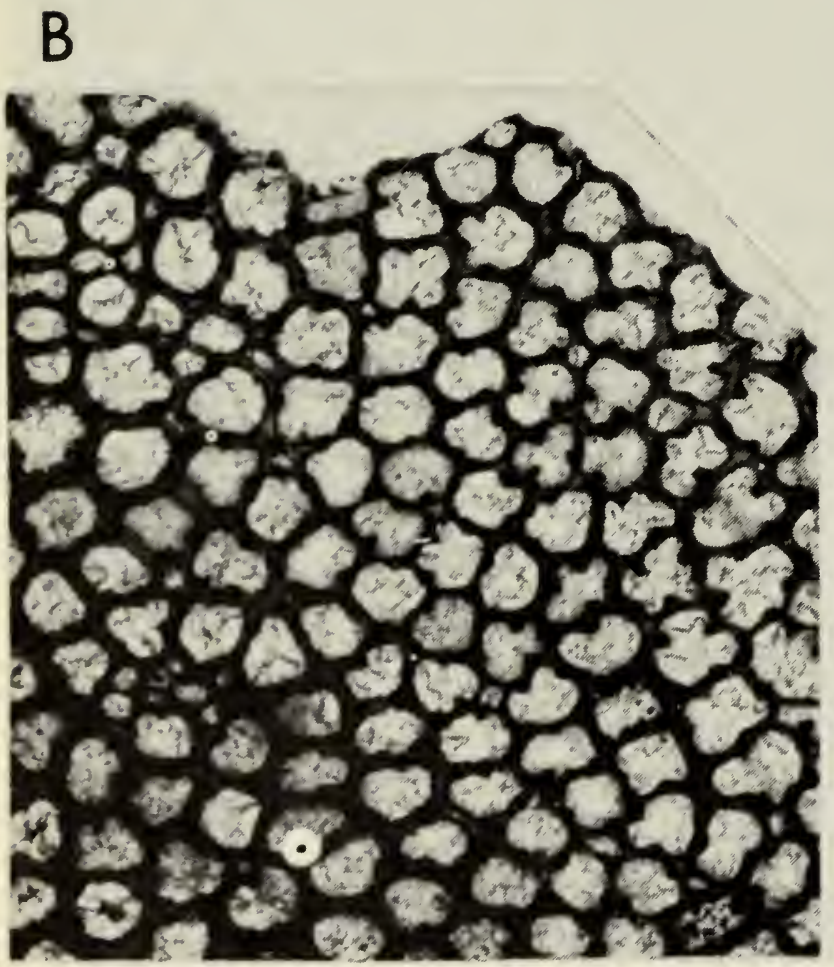

Fig. 3 A-C. Heterotrypa robusta Dyer, $\times 30$. Longitudinal section, ROM 12156.

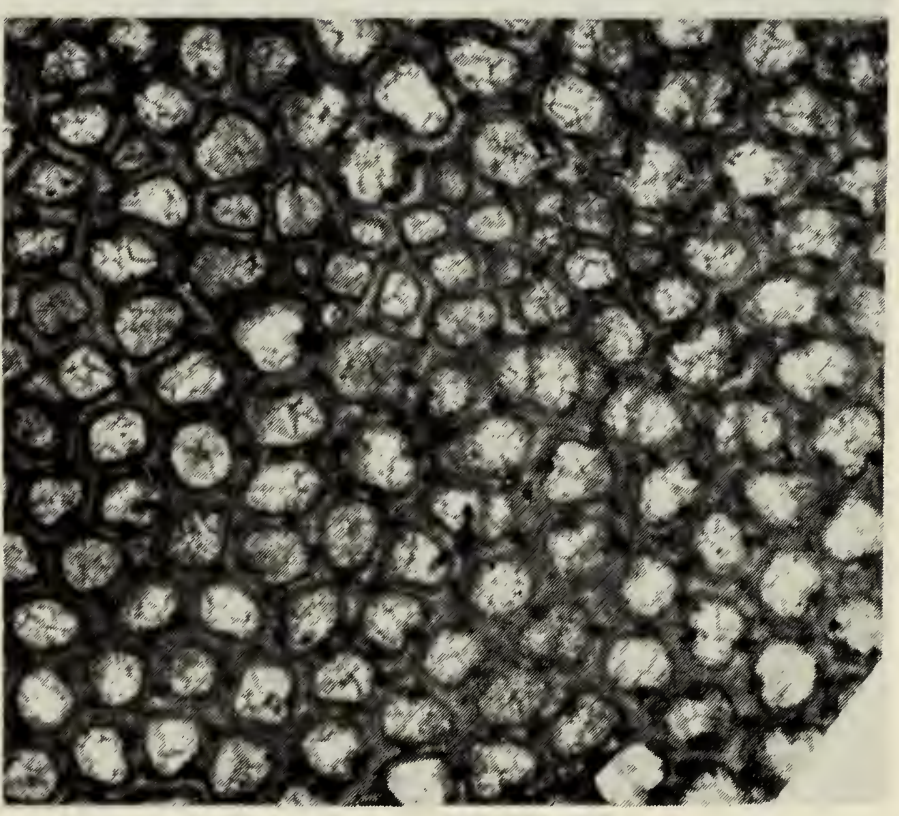

B. Tangential section, Rом 12156

C. Tangential section, ROM 12157. 


\section{Emended Description}

\section{EXTERNAL FEATURES}

Zoarium frondescent to ramose, frondescent fragment measures $20 \times 20 \times 7 \mathrm{~mm}$; only bases of branches preserved, diameter of largest branch $6 \mathrm{~mm}$. Surface with prominent, low-rounded monticules 2 to $2.5 \mathrm{~mm}$ apart measuring from centre to centre. Acanthopores protrude at surface, giving it a spiny appearance. The distinctive monticulose surface distinguishes this species from any other Heterotrypa in the collection.

\section{TANGENTIAL SECTION}

In deep sections zooecial apertures angular to subangular, becoming subcircular to nearly circular near surface (Fig. 2A). Zooecial wall 0.01 to $0.02 \mathrm{~mm}$ thick in deep sections, average width towards surface $0.05 \mathrm{~mm}$, but may reach $0.09 \mathrm{~mm}$ in monticules; number of zooecia in $2 \mathrm{~mm} 9$ to 9.5 (Table 2). Wall concentrically laminated, dark and thick at growing edge where laminae compact, below this zone prominent light-coloured ring present; at depth where wall thin, faint dark line of demarcation often visible, thin ring of light-coloured laminae lines zooecial cavity. Mesopores, generally triangular or quadrangular, in axial region commonly situated between adjacent zooecia, some mesopores pinch out or become smaller before reaching surface where zooecial apertures are more circular, 0-20 mesopores in $1 \mathrm{~mm}^{2}$ in intermonticular area (Table 2). Acanthopores range in diameter from 0.01 to $0.1 \mathrm{~mm}$, most fall within range 0.03 to $0.5 \mathrm{~mm}$, number in $1 \mathrm{~mm}^{2}$ in intermonticular area 5 to 12 (Table 2). Monticules composed of larger zooecia than those in intermonticular area, and a few small, angular mesopores indiscriminately disposed, apertural diameter of zooecia in monticules 0.19 to $0.29 \mathrm{~mm}$ (Table 2), apertural diameter of zooecia in intermonticular area 0.14 to $0.22 \mathrm{~mm}$ (Table 2).

\section{LONGITUDINAL SECTION}

Zooecia curve broadly from axial zone to periphery intersecting zoarial surface at low oblique angle (Figs. 2B, 5c). Zooecial wall thin and straight in axial region, thickening progressively from base of peripheral zone to surface and becoming moderately moniliform, diaphragms often join wall where monilae thickest (Boardman, 1960). Wall dense at growing edge where laminae compact, below which, throughout mature zone, median light-coloured area; as wall becomes thin in axial zone faint dark line of demarcation visible. Wall laminae relatively coarse, alternating light and dark in colour, convex outward in peripheral region, diverging at a low angle from median light band and merging with the light-coloured, laminar lining of zooecial cavity to continue into diaphragms in zooecia and mesopores. Diaphragms straight in axial zone, one to two tube diameters apart; more closely spaced as growth proceeds, in peripheral zone some are less than one tube diameter apart, are straight, concave, oblique, or even cyst-like (Figs. 2B, 5C). Mesopores in peripheral zone often bead-like, with diaphragms closer than in zooecia. Acanthopores in peripheral zone with central lumen, on either side of which laminae diverge at moderate angle and pass into zooecia and mesopores. Acanthopores protrude beyond zoarial surface.

\section{Remarks}

It is clear that Dyer's plesiotype is closely related to Atactopora subramosa Ulrich (1879), and to Heterotrypa prolifica Ulrich (1890). In their study of $H$. subramosa 
from Ohio and Indiana, Utgaard and Perry (1964) considered these two species as synonyms. It should be noted, however, that the zoarium of $H$. prolifica, as originally described, possessed low, rounded tuberosities (i.e. monticules), a characteristic feature of the Credit Valley type, while H. subramosa, as originally described, lacked monticules. Utgaard and Perry (1964) made no point of this difference, although the specimens they described possessed monticules. Qualitatively the present taxon is similar to the fauna from Ohio and Indiana in external form and in all microscopic counts. When the Credit species is compared quantitatively with data available from Utgaard and Perry's type, no significant difference is noted; therefore, from the available evidence I am of the opinion that Dyer's plesiotype should be designated $H$. subramosa.

\section{Locality}

Meaford Formation, Erindale Member, Cooksville, Ontario.

Type

Plesiotype ROM 12226.

\section{Heterotrypa robusta Dyer, 1925 \\ Figs. $3 \mathrm{~A}-\mathrm{C}, 4 \mathrm{~A}-\mathrm{C}$}

\section{Original Description (Dyer, 1925)}

In the Streetsville member, several specimens of a coarse, ramose, smooth-surfaced bryozoan were found, in which the zoarium varies from 12 to $15 \mathrm{~mm}$ in diameter.

In tangential sections, the outstanding features of the species are the strong inflection of walls by the acanthopores and the fact that most of these acanthopores are found between the angles of junction of the zooecial walls. They are fairly numerous and of medium size. The zooecial tubes are small, 11 being found in a space of two millimetres. The mesopores are not numerous and are usually distributed evenly throughout the zoarium but are occasionally gathered into maculae.

In some parts of the tangential sections, distinct dark boundaries are seen between the adjacent zooecial walls, while in other parts of the same sections no evidence of a separation is visible, the walls being completely fused. Less diversity is seen in the immature region where the walls are usually separate. The variability in this respect leads to the conclusion that the fusion of the walls is not a specific feature. A similar conclusion was reached with regard to other species. In view of these observations the writer is inclined to question the value of subdividing the trepostomatous bryozoans into Integrata and Amalgamata.

In longitudinal sections the axial portion is seen to be comparatively small, with a diameter not more than one-half that of the whole zoarium. In this axial part the tubes run upward and outward with very thin and crenulated walls. There are no diaphragms. On reaching the mature zone, the tubes turn abruptly and run directly to the surface of the zoarium at the same time becoming thick-walled. In this zone the walls are even and straight with a slight suggestion of periodic thickening. Diaphragms are present with a distance equalling one tube diameter between them. Mesopores and acanthopores are seldom seen in longitudinal sections.

\section{Emended Description}

EXTERNAL FEATURES

Zoarium of stout, slightly compressed branches, maximum diameter $18 \times 25 \mathrm{~mm}$, surface with small monticules occurring at regular intervals of 2 to $2.5 \mathrm{~mm}$, meas- 
ured from centre to centre. Prominent, small rounded elevations of various sizes, representing aborted branches and best shown on syntypes 12157,12158 , give the surface a knobby appearance.

TANGENTIAL SECTION

Dyer's sections are poor; new sections prepared for this study have furnished detail hitherto unrecognized. Zooecial apertures near surface subangular to circular, walls thick, moderately inflected by acanthopores (Figs. 3c, 4c); walls in deeper sections somewhat thinner, zooecial apertures petaloid owing to pronounced inflection of acanthopores (Figs. 3B, 4B); in thinner-walled axial zone acanthopores only slightly inflecting, confined to angles of junction of zooecia. Zooecia 10 to 11.5 in $2 \mathrm{~mm}$ (Table 3), walls 0.01 to $0.02 \mathrm{~mm}$ thick in axial zone, 0.04 to $0.07 \mathrm{~mm}$ thick in mature zone to $0.09 \mathrm{~mm}$ thick in monticules; wall concentrically laminated, dense at surface because of closely packed laminae below surface wall with median light-coloured ring; in axial zone, where wall thinnest, faint dark line of demarcation present. Mesopores mostly subcircular, few and small in intermonticular areas, number in $1 \mathrm{~mm}^{2}$ in intermonticular area 1 to 4 (Table 3). Acanthopores abundant, 42 to 58 in $1 \mathrm{~mm}^{2}$ in intermonticular area (Table 3), diameter 0.02 to $0.07 \mathrm{~mm}$, small central lumen surrounded by concentric laminae. Zooecia on periphery of monticules larger than those in intermonticular areas, centres of monticules with groups of relatively large mesopores. Maximum apertural diameter in $\mathrm{mm}$ of zooecia in monticules 0.14-0.20 (Table 3). Maximum apertural diameter in $\mathrm{mm}$ of zooecia in intermonticular area 0.10-0.16 (Table 3).

\section{LONGITUDINAL SECTION}

Zooecia usually curve out broadly from base, in late axial region turn abruptly to intersect zoarial surface nearly at right angles (Fig. 3A). However, where an overgrowth occurs initial zooecia subprostrate for short distance, then straighten and continue to surface where they open approximately at right angles (Fig. 3A). Zooecial walls thin, straight, or sinuous in axial zone with periodic fine crenulation, at wide intervals a solitary monila occurs at same level across section; walls throughout the long peripheral zone becoming moniliform; wall laminae in latter zone alternating light and dark in colour, light colour believed due to presence of very fine granules; laminae convex outward, diverging at moderate angle of between 30 and $40^{\circ}$ from light-coloured median area; at depth where wall thinnest median light area replaced by faint dark line of demarcation. Diaphragms few in axial zone, one or two in sub-peripheral zone, numerous in peripheral zone, straight to concave, spaced usually one to two zooecial diameters apart; where diaphragms located adjacent to wall monilae (Boardman, 1960), i.e. usually where monilae thickest, monilar laminae show most clearly passage into diaphragms. Mesopores rarely detected except where section cuts a monticule, in which case several adjacent mesopores occur each with diaphragms spaced apart one or two tube diameters. Acanthopores best observed in mature zone where the small central lumen is flanked by laminae which diverge outward at a moderate angle and pass into the zooecia and mesopores.

\section{Remarks}

Dyer stated that $H$. robusta resembled $H$. microstigma Cumings and Galloway (1913) more closely than any other species. I have examined the holotype of H. microstigma, IU4646, 9122-22,23 from Waynesville (Lower Richmond) in Cut 13 


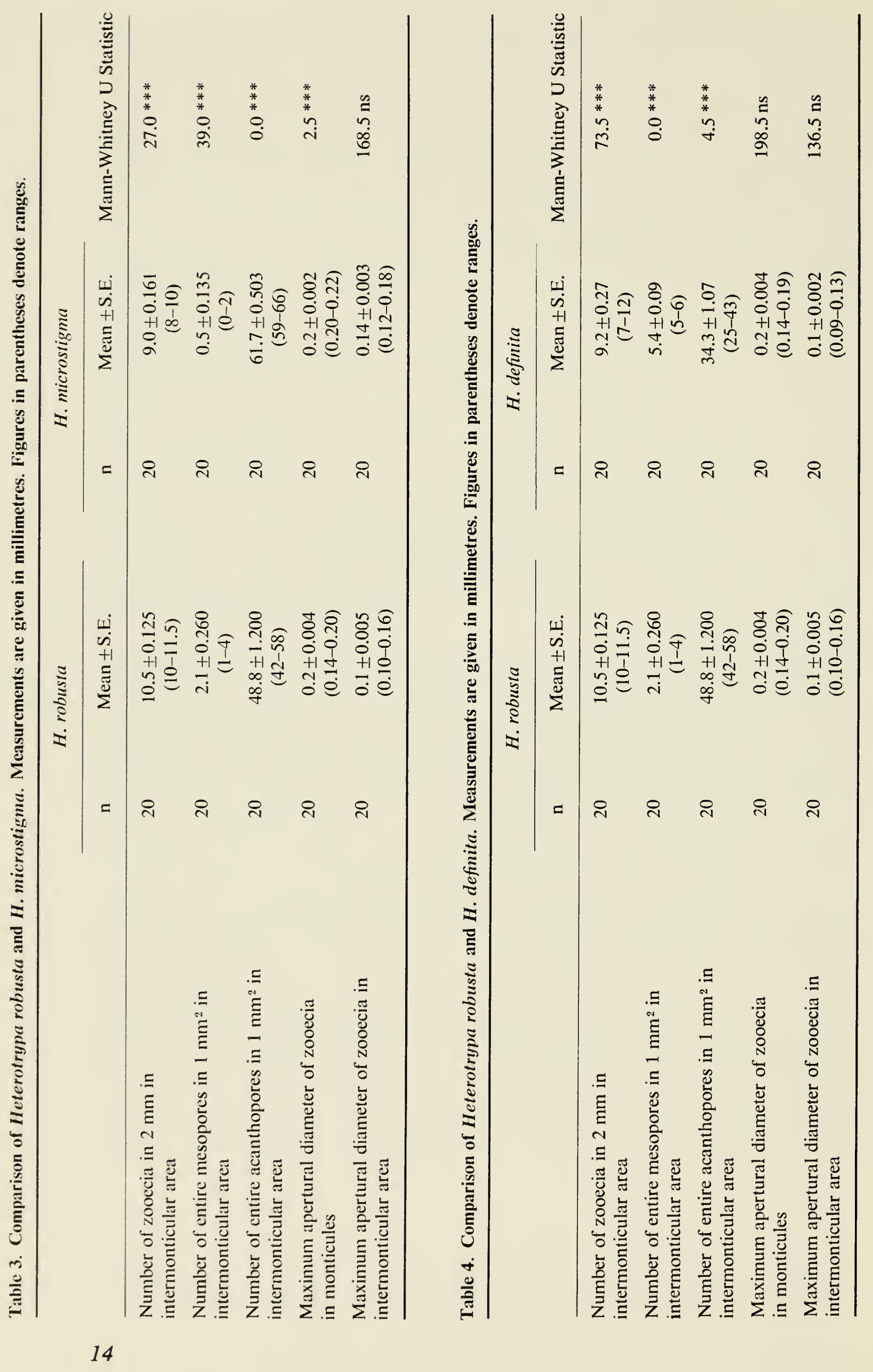


on the Big Four Railroad near Weisburg, Indiana, which was kindly lent to me by the late Professor T.G. Perry of Indiana University. The Waynesville Formation is not now recognized by the Indiana Geological Survey, and the entire Maysville and Lower Richmond up to the Saluda Limestone is included in the Dillsboro Formation.

Externally the zoarium of this type does not exceed 7 or $8 \times 11 \mathrm{~mm}$ in diameter as compared with $18 \times 25 \mathrm{~mm}$ in $H$. robusta. Qualitatively zooecia in $H$. robusta are smaller, mesopores more numerous, and acanthopores fewer than in $H$. microstigma. Quantitatively the two species differ significantly in number of zooecia in $2 \mathrm{~mm}$ in intermonticular area, number of entire mesopores in $1 \mathrm{~mm}^{2}$ in intermonticular area, number of entire acanthopores in $1 \mathrm{~mm}^{2}$ in intermonticular area, and in the maximum apertural diameter of zooecia in monticules (Table 3 ). I believe the two species to be distinctly different.

$H$. robusta and $H$. definita are similar in the shape of the zoarium, but the knobby surface of the former is lacking in the latter. However, they differ in microscopic detail. In $H$. robusta the centres of the monticules are composed of relatively large and small mesopores whereas in $H$. definita the centres of the monticules have conspicuous clusters of numerous small mesopores of characteristic stellate shape, mesopores in the intermonticular space are fewer, and acanthopores are more numerous in $H$. robusta than in $H$. definita. The two species compared quantitatively (Table 4) show that significant differences occur in the number of zooecia in $2 \mathrm{~mm}$ in the intermonticular area, in the number of mesopores in $1 \mathrm{~mm}^{2}$ and in the number of acanthopores in $1 \mathrm{~mm}^{2}$ in the intermonticular area. They therefore represent separate species.

\section{Locality}

Meaford Formation, Upper Ordovician, Credit River, Streetsville, Ontario.

Type

Syntypes ROM 12156, ROM 12157, ROM 12158.

\section{Heterotrypa simplex Dyer, 1925}

Figs. 2C-D, 5D

\section{Dyer's Description (1925)}

This species is rather common in the Streetsville member where it forms ramose or subramose, smooth-surfaced zoaria, with an average diameter of $10 \mathrm{~mm}$, as in $H$. simplex maculosa (Plate vir, Figure 10).

In tangential sections, it is seen that the tubes are of a very uniform size and rather small, twelve being found on the average in a distance of two millimetres. Mesopores are entirely absent. Acanthopores are numerous, comparatively small, and the regularity of their distribution is remarkable, one being found at each angle of junction of the zooecial wall. Very rarely is a departure from this occurrence found.

In vertical sections, Heterotrypa simplex is almost identical with H. robusta (Plate II, Figure 7). The structure is so similar, as thus revealed, that a repetition of the description is unnecessary.

In internal characters, Heterotrypa simplex resembles $H$. solitaria, Ulrich, of the Fairmount, but this species is frondescent rather than ramose in its manner of growth. From all other species of Bryozoa occurring in the Credit River Section, the present species may be distinguished by the very regular arrangement of the acanthopores and the entire absence of mesopores. 


\section{Emended Description}

\section{EXTERNAL FEATURES}

Known only from a small fragment consisting of round to flattened branches 8 to $10 \mathrm{~mm}$ in diameter, surface with small, slightly elevated monticules, $1-1 \frac{1}{2}$ to $2 \mathrm{~mm}$ apart, measuring from centre to centre, composed of zooecia larger than in intermonticular areas and a few relatively large mesopores; acanthopores numerous and prominent.

\section{TANGENTIAL SECTION}

Zooecial apertures angular to subcircular and ihick-walled at surface becoming angular and progressively thinner-walled at depth (Figs. 2C, 5D), 11 to 12 commonly in $2 \mathrm{~mm}$ (Table 5), walls 0.01 to $0.02 \mathrm{~mm}$ thick in deep sections, 0.03 to $0.05 \mathrm{~mm}$ thick near surface, maximum $0.07 \mathrm{~mm}$ in monticules; wall concentrically laminated, dense at surface where laminae compact, below which, in peripheral zone, laminae display light-coloured ring; at greater depth where wall thinnest, laminae obscure, faint dark line of demarcation present. Mesopores few in intermonticular area (Figs. 2C, 5D), number in $1 \mathrm{~mm}^{2} 0$ to 3 (Table 5). Acanthopores numerous, 28 to 46 in $1 \mathrm{~mm}^{2}$ in intermonticular area (Table 5), situated in the zooecial angles, never inflecting, 0.01 to $0.04 \mathrm{~mm}$ in diameter, normally $0.03 \mathrm{~mm}$, composed of laminae surrounding a small central lumen. Monticules with larger zooecia and with thicker walls than in intermonticular areas and with very few mesopores not in clusters (Figs. 2C, 5D), maxinum apertural diameter of zooecia in $\mathrm{mm}$ in monticular area 0.14 to 0.22 (Table 5); maximum apertural diameter of zooecia in intermonticular area 0.09 to 0.13 (Table 5).

\section{LONGITUDINAL SECTION}

Zooecia swing outward in a broad curve to open at approximately right angles on reaching surface (Fig. 2D); walls thin in axial zone, straight to finely crenulate, thicken gradually from outer axial and inner sub-peripheral zones, becoming relatively thick, in places moniliform in moderately long peripheral zone; wall concentrically laminated, laminae best seen in peripheral zone, convex outward, diverging at an angle of $35^{\circ}$ to $40^{\circ}$ from a median light-coloured area (lumen) then passing into diaphragms. Laminae granulose, alternating light and dark, light laminae possibly more finely granulose. Diaphragms in the outer axial zone where one or two occur, thereafter diaphragms mostly straight, numerous, commonly $\frac{1}{2}$ to 1 tube diameter apart (Fig. 2D). Acanthopores best observed in peripheral zone where they at times cut across the trend of a zooecium, consist of a light-coloured, central lumen, from which laminae diverge at a moderately low angle and pass into diaphragms in zooecia or mesopores.

\section{Remarks}

Dyer stated that $H$. simplex resembled $H$. solitaria Ulrich (1883). I have not had access to Ulrich's holotype (USNM 43664) but after carefully reading his description and examining his figures I have come to the conclusion that the two species have little in common. The closest relationship between $H$. simplex and the present fauna is with $H$. robusta and $H$. definita.

The one small fragment of the type of $H$. simplex which exists has the knobby surface of $H$. robusta. Also, when the two are compared qualitatively they differ in microscopic detail, namely, number of zooecia in $2 \mathrm{~mm}$ in intermonticular area, 


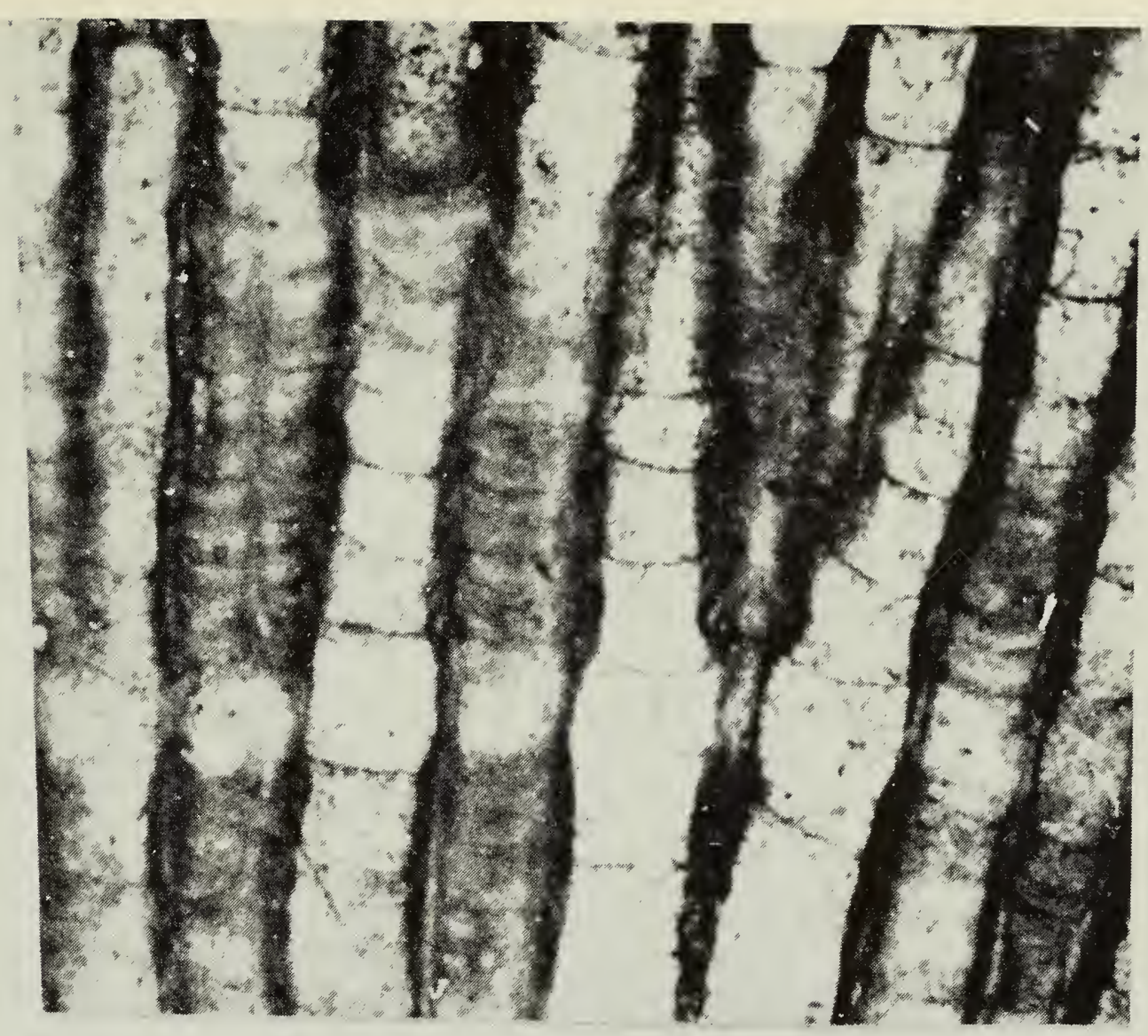

A

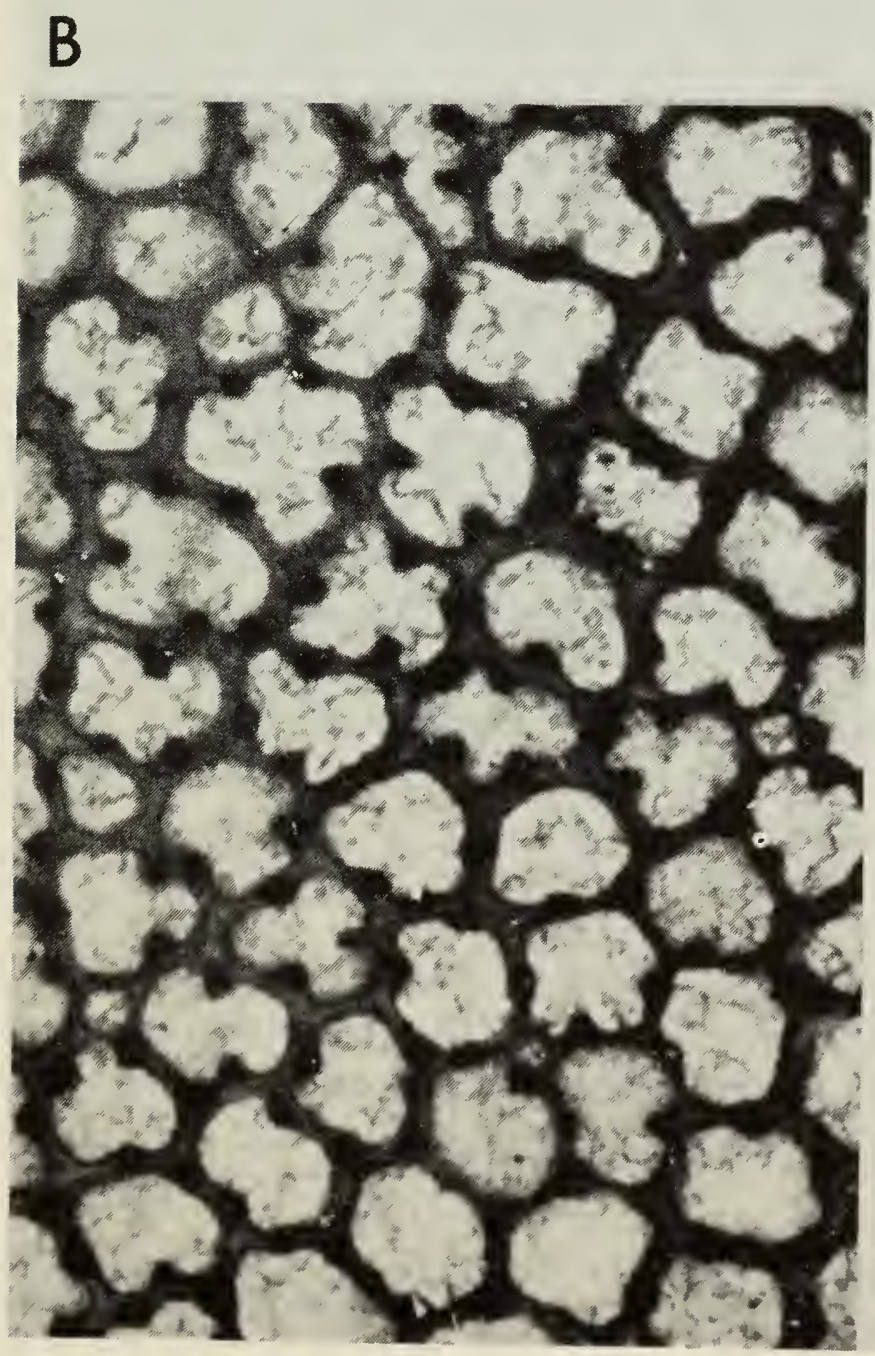

Fig. 4 A-C. Heterotrypa robusta Dyer, $\times 60$. A. Longitudinal section, ROM 12156.

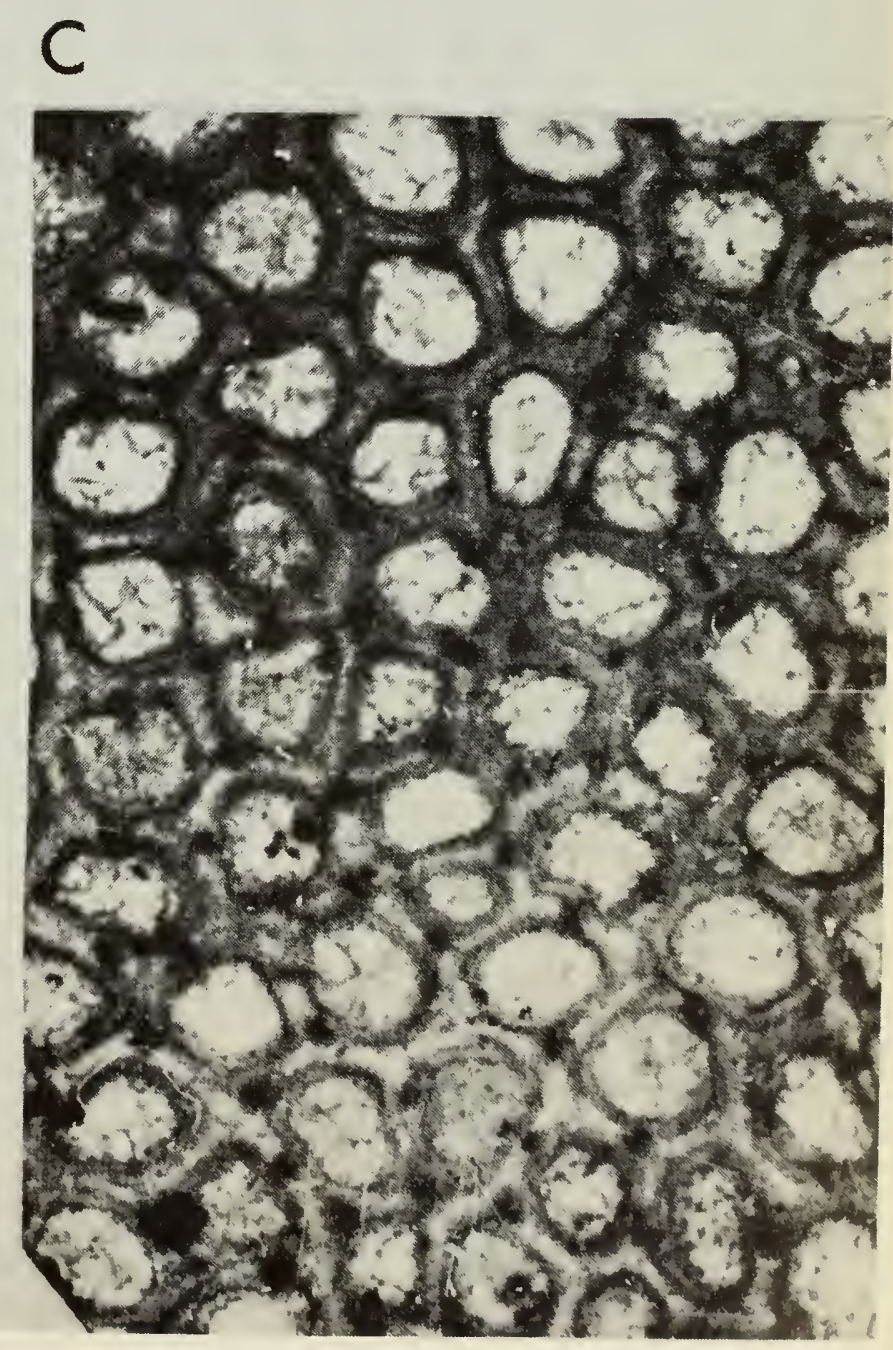

B. Deep tangential section, Rom 12156.

C. Tangential near surface, ROM 12157. 
number of entire mesopores in $1 \mathrm{~mm}^{2}$ in intermonticular area, number of entire acanthopores in $1 \mathrm{~mm}^{2}$ in intermonticular area, maximum apertural diameter of zooecia in monticules, and maximum apertural diameter of zooecia in monticules, and maximum apertural diameter of zooecia in intermonticular area (Table 5). Compared quantitatively, the two differ significantly in the number of zooecia in $2 \mathrm{~mm}$ in intermonticular area, number of entire mesopores in $1 \mathrm{~mm}^{2}$ in intermonticular area, number of acanthopores in $1 \mathrm{~mm}^{2}$ in intermonticular area, and in the apertural diameter of zooecia in $\mathrm{mm}$ in the intermonticular area (Table 5).

$H$. simplex and $H$. definita are similar in zoarial shape but the latter lacks the knobby surface; furthermore, the monticulcs in $H$. simplex lack the central, stellate clusters of small mesopores characteristic of $H$. definita. In $H$. simplex the number of zooecia in $2 \mathrm{~mm}$ in the intermonticular area is 11 to 12 , compared with 7 to 12 in $H$. definita (Table 6), and fewer mesopores occur in $1 \mathrm{~mm}^{2}$ in $H$. simplex. When compared quantitatively, the two species show significant differences in the nuimber of zooecia in $2 \mathrm{~mm}$ (Table 6) and in the number of entire mesopores in $1 \mathrm{~mm}^{2}$ (Table 6).

\section{Locality}

Meaford Formation, Streetsville, Ontario.

Type

Holotype ROM 12159.

\section{Heterotrypa simplex maculosa var.nov., Dyer, 1925}

Figs. 5A-B, 6A-B

\section{Original Description (Dyer, 1925)}

The above variety differs from Heterotrypa simplex only in the occurrence of maculae. These are placed at wide irregular intervals over the surface of the zoarium and are not raised above the general level of the zoarial surface. They are composed of mesopores, five to twenty in number, and in certain places are surrounded by zooecia larger than the average.

In both Heterotrypa simplex and $H$. simplex maculosa, quite definite boundaries between the zooecia are seen in sub-mature regions, but, as in Heterotrypa robusta, the walls become fused in the mature regions.

The variety occurs in the Streetsville member, very often in association with Heterotrypa simplex.

\section{Emended Description}

EXTERNAL FEATURES

Zoarium ramose, round branches with diameter $10 \mathrm{~mm}$, flattened branches 7 by $15 \mathrm{~mm}$. Surface with small, closely spaced, slightly elevated monticules (maculae of Dyer) averaging $1.5 \mathrm{~mm}$ apart, measuring centre to centre, centres composed of groups of mesopores surrounded by larger zooecia.

\section{TANGENTIAL SECTION}

Zooecial apertures angular at depth, subangular to subcircular, nearly circular where wall thickest at zoarial surface (Fig. 6A), generally 10.5 to 12 in $2 \mathrm{~mm}$ 
(Table 7). Zooecial walls $0.01 \mathrm{~mm}$ (or less) thick in deep parts of section, typically 0.02 to $0.03 \mathrm{~mm}$ thick in sections near surface, and as much as $0.07 \mathrm{~mm}$ thick in monticules; wall concentrically laminated with light-coloured median ring in peripheral region, faint dark line of demarcation in axial region. Mesopores almost absent in intermonticular areas (Table 7). Acanthopores numerous, situated in the zooecial angles and not inflecting the apertures (Table 7), fairly uniform in size. diameter commonly 0.02 to $0.03 \mathrm{~mm}$, composed of laminae surrounding a small central lumen. Monticules with central clusters of small mesopores, numbering as many as 25 in a cluster, and surrounded by zooecia larger than those in the intermonticular areas (Fig. 6A). In monticules diameter $(\mathrm{mm})$ of zooecial apertures in $1 \mathrm{~mm}^{2} 0.15$ to 0.23 (Table 7); in intermonticular area diameter of zooecia in $1 \mathrm{~mm}^{2} 0.09$ to 0.13 (Table 7 ).

\title{
LONGITUDINAL SECTION
}

Zooecia curve broadly (locally sharply) from axial into peripheral zone then continue in a straight course to intersect zoarial surface at right angles or nearly so (Fig. 6B); walls straight, wavy, occasionally finely crenulate in axial portion, gradually thickening in outer axial region, thickening appreciably and becoming periodically moniliform throughout passage of relatively long peripheral zone; wall laminated, laminae convex outward and diverging at a low angle and passing into the diaphragms; diaphragms appear in outer axial region, becoming more numerous in peripheral zone where they are spaced from $\frac{1}{2}$ to 2 tube diameters apart. Acanthopores, prominent in peripheral zone, appear to be a facsimile of their counterpart in Heterotrypa simplex. Sections cutting through a monticule show central cluster of small mesopores with closely set diaphragms, the cluster bounded by larger zooecia.

\section{Remarks}

The presence of clusters of small mesopores comprising the centres of the monticules (maculae of Dyer) distinguish this subspecies from $H$. simplex; otherwise the two are very similar when compared qualitatively. Quantitatively significant differences occur in the number of entire acanthopores in $1 \mathrm{~mm}^{2}$ in the inter monticular area (Table 7), and in the mm measurements of maximum apertural diameter of zooecia in the monticules (Table 7). The only other associated taxa, having clustered mesopores, with which $H$. simplex maculosa might be confused is $H$. definita. In the former the clusters of mesopores are solid (or nearly so), in the latter they are more loosely assembled, characteristically stellate in shape. Compared quantitatively the two differ significantly in all computed measurements (Table 8). H. simplex maculosa is herein considered to be the species, H. maculosa.

\author{
Locality \\ Meaford Formation, Streetsville, Credit River, Ontario.
}

\section{Type}

Syntypes ROM 12160, 12175 . 


\section{Heterotrypa meafordensis Fritz, 1974 (New Status) (Heterotrypa subpulchella parvulipora Dyer, 1925, var. nov.)}

Fig. 6C-D

\section{Dyer's Original Description (1925)}

Among the older collections of Bryozoa from Streetsville in the Royal Ontario Museum of Palaeontology, one specimen was found which closely resembles Heterotrypa subpulchella (Nicholson), of the Maysville of Ohio. In form it is a flattened sub-ramose mass, measuring $32 \mathrm{~mm}$ in length, $20 \mathrm{~mm}$ in width, and $13 \mathrm{~mm}$ in height. It probably branched, since the broken bases of branches are still seen. Maculae are scattered over the surface of the zoarium, with an average distance of one millimetre between them. They are scarcely raised above the general surface of the zoarium.

The variety resembles the type in tangential sections, particularly in the character of the maculae, which consist of mesopores to the number of 10 or 15 in each, surrounded by zooecial tubes of distinctly larger than average size. The acanthopores are numerous and vary considerably in size, some of them being abnormally large. They are usually found between the angles of junction of the zooecial walls. The zooecia of the new variety are smaller than in the type of the species, 11 to 12 being found in two millimetres, in the former; while in the latter, no specimens have been recorded in which they are more numerous than nine in two millimetres, and according to Nicholson there are only six to seven tubes in this distance. This is the most outstanding difference between the two forms. Another difference is that in $H$. subpulchella parvulipora, the mesopores are confined to the maculae, while in Nicholson's species they are sometimes found between the maculae.

The two forms are very similar in vertical sections. They possess thin, crenulated walls, with the average number of diaphragms for the genus to which they are referred. Even here, however, there is a different, $H$. subpulchella having more diaphragms in the axial region than $H$. subpulchella parvulipora.

\section{Emended Description}

\section{EXTERNAL FEATURES}

Zoarium fragmentary, composed of branches given off irregularly, largest of which is $10 \mathrm{~mm}$ in diameter; surface with randomly disposed, mamelon-like elevations $1 \mathrm{~mm}$ in height, diameter at base 2 to $4 \mathrm{~mm}$, suggesting aborted branches; small flat-topped monticules approximately 2 to $2.5 \mathrm{~mm}$ apart occur. Pyritization has obliterated the microstructure except in certain areas.

\section{TANGENTIAL SECTION}

Zooecial apertures subangular to nearly circular in sections near surface, angular and with thinner walls at depth (Fig. 6D); 11 to 11.5 commonly in $2 \mathrm{~mm}$ (Table 9), zooecial walls 0.01 to $0.02 \mathrm{~mm}$ thick in deep sections, 0.02 to $0.06 \mathrm{~mm}$ near surface and up to $0.09 \mathrm{~mm}$ thick in monticules; wall concentrically laminated, individual

Fig. 5 A-F, $\times 60$.

A-B. Heterotrypa simplex maculosa Dyer.

A. Longitudinal section, ROM 12175.

B. Tangential section, Rом 12175 .

C. Heterotrypa prolifica Ulrich Longitudinal section, ROM 12226.

D. Heterotrypa simplex Dyer Tangential section, ROM 12159.

E-F. Heterotrypa definita Dyer.

E. Longitudinal section, ROM 12154 .

F. Tangential section, ROM 12154 . 

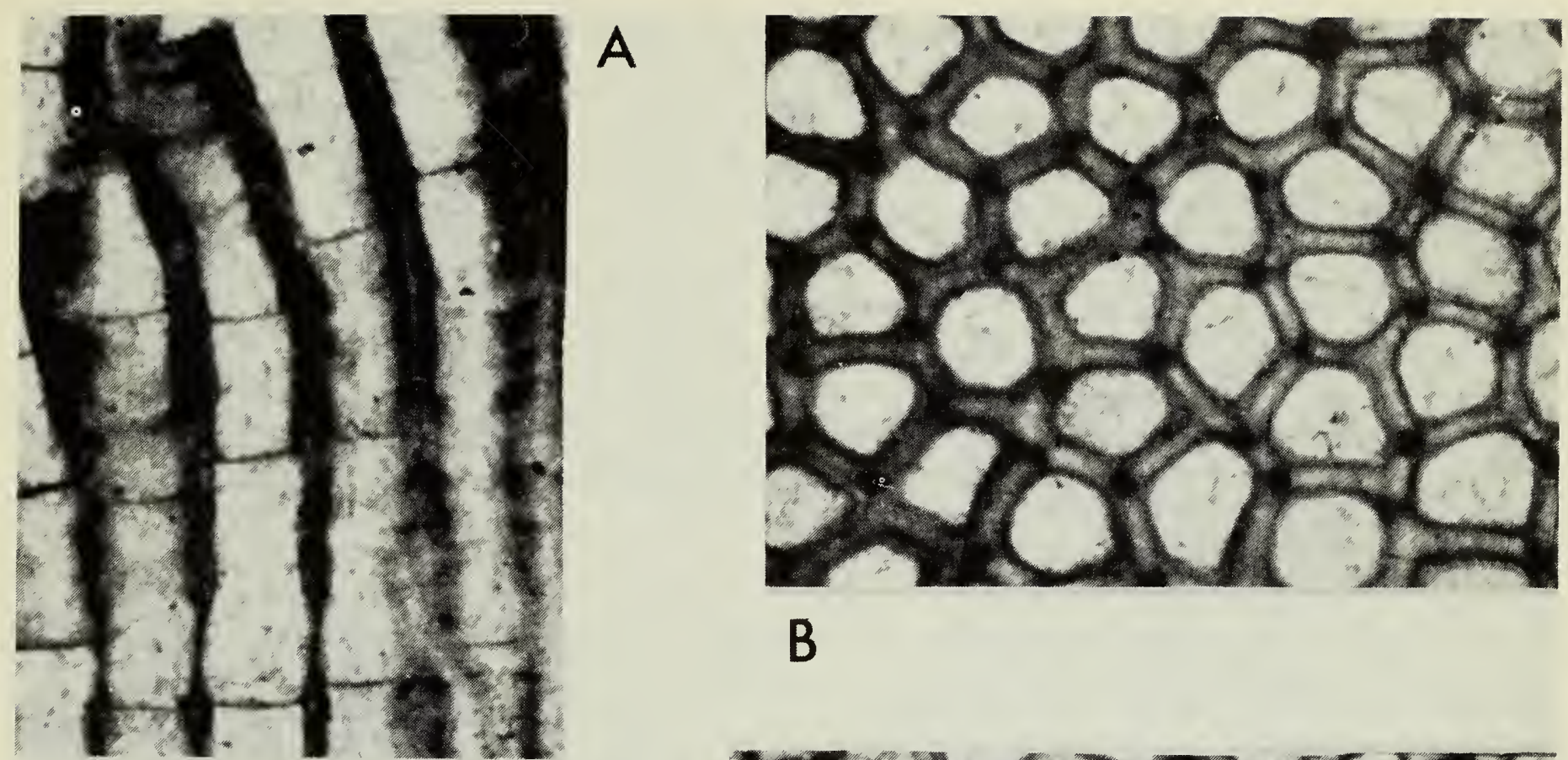

B
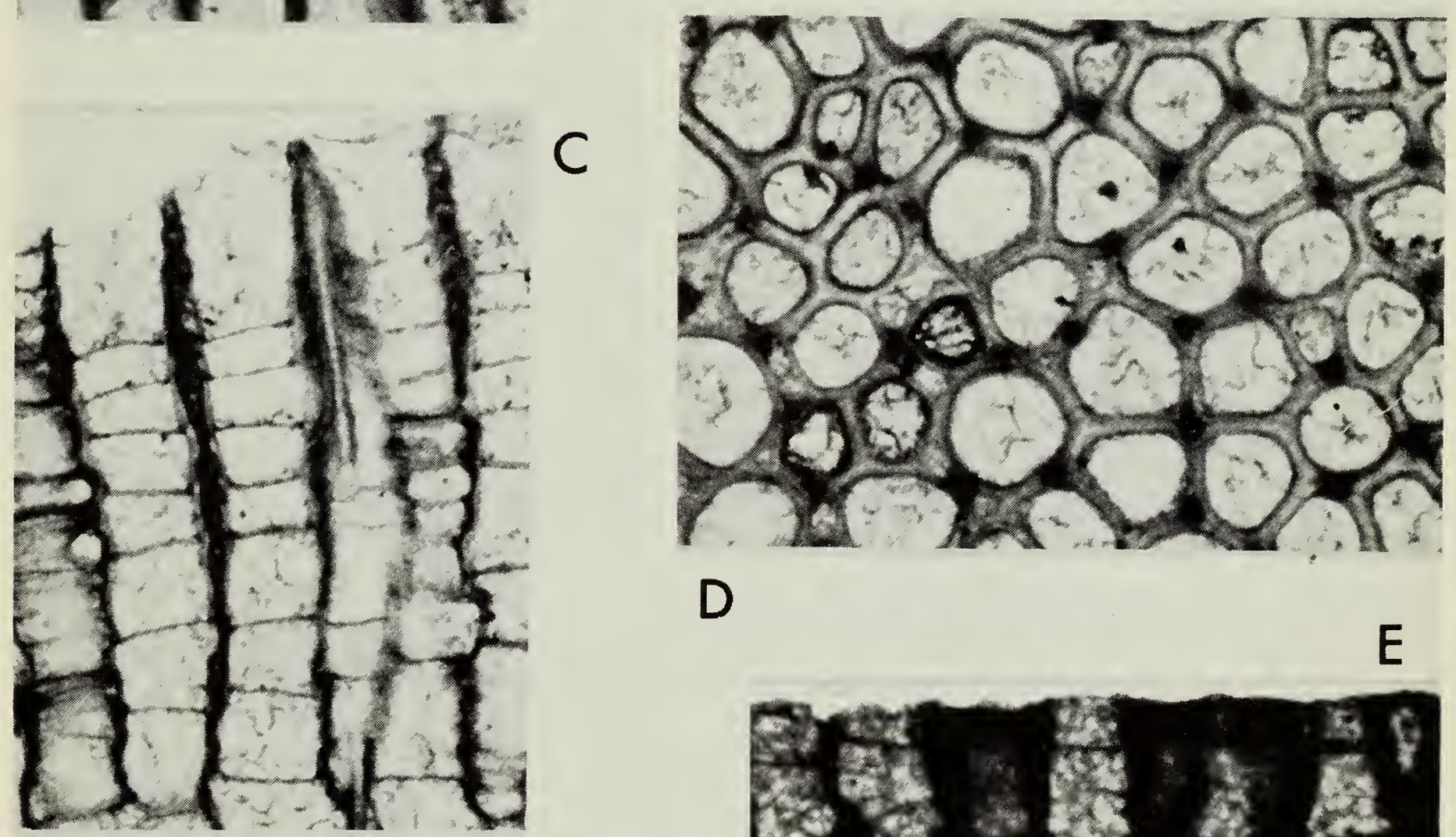

D

E

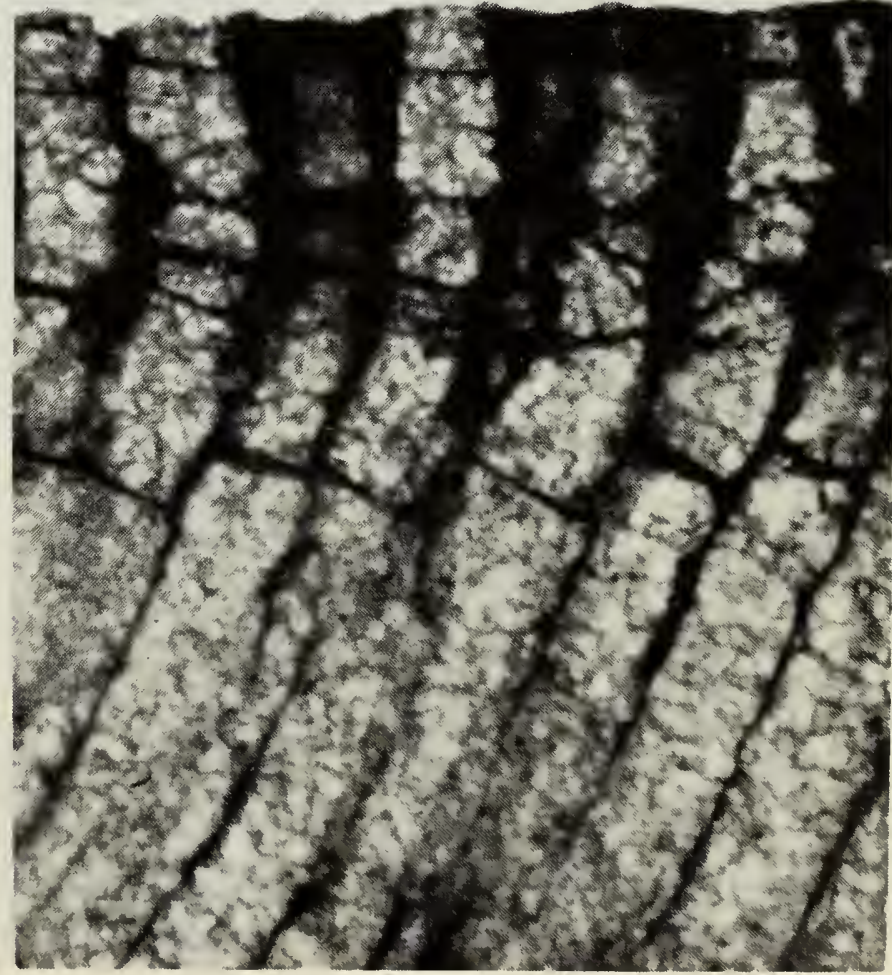


laminae with granules very clearly visible at growing edge, below which median light-coloured ring present, replaced at depth by thin dark line of demarcation. Number of mesopores in intermonticular area 1 to 6 (Table 9). Acanthopores situated in zooecial angles, seldom inflecting, commonly 1 to 3 where three zooecia are in conjunction, composed of concentric laminae surrounding a central lumen, diameter 0.02 to $0.06 \mathrm{~mm}, 1$ to 4 in $1 \mathrm{~mm}^{2}$ (Table 9). Monticules with central clusters of mesopores, surrounded by zooecia larger and with thicker walls than those in intermonticular area. In monticules diameter of zooecia in $\mathrm{mm} 0.18$ to 0.24 (Table 9). In intermonticular area diameter of zooecia in $\mathrm{mm} 0.10$ to 0.14 (Table 9).

\section{LONGITUDINAL SECTION}

Zooecia curve broadly outward to open at surface nearly at right angles (Fig. 6c); wall thin, straight or coarsely crenulated in axial zone, thickening gradually from the outer axial zone and early peripheral zone, becoming relatively thick and moniliform throughout remainder of peripheral zone (Fig. 6c); walls concentrically laminated, individual laminae clearly defined, dark in colour alternating with clear areas where laminae are more finely granulose. Laminae convex outward diverging from central area at relatively low angle and passing into diaphragms. Diaphragms absent in early axial zone, 1 or 2 present in passage to peripheral zone, becoming numerous thereafter and spaced from $\frac{1}{2}$ to 2 tube diameters apart. Acanthopores in peripheral zone show convex laminae diverging from comparatively large lumen at moderately low angle to continue into zooecia and diaphragms.

\section{Remarks}

This variety is not to be confused with Heterotrypa parvulipora Ulrich and Bassler (1904), the type specimen of which comes from the Catheys Limestone of the Trenton, along Love Branch of Catheys Creek in Maury County, Tennessee. I disagree with Dyer in his associating the "variety" with $H$. subpulchella Nicholson (1875): for one reason the zoarium of $H$. subpulchella consists of "ramose compressed branches which may be quite frondescent and are partially hollow centrally." Furthermore, in the matter of internal structure the most striking difference lies in the non-crenulate, non-moniliform character of the zooecial walls in $H$. subpulchella, an obvious feature of Dyer's "variety". Of the associated fauna, $H$. meafordensis and $H$. robusta are alike in shape and knobby surface, but in thin sections the zooecial walls of the present form are coarsely crenulated with occasional prominent monilae. The monticular pattern resembles that of $H$. definita in that the central clusters of mesopores are somewhat stellate in shape, but differs from it in the knobby surface of the zoarium.

Fig. 6 A-D, $\times 30$.

A-B. Heterotrypa simplex maculosa Dyer.

A. Tangential section, ROM 12175.

B. Longitudinal section, ROM 12175.

C-D. Heterotrypa meafordensis, Fritz.

C. Longitudinal section, ROM 12161.

D. Tangential section, ROM 12161 . 
ऊ4t

B

A

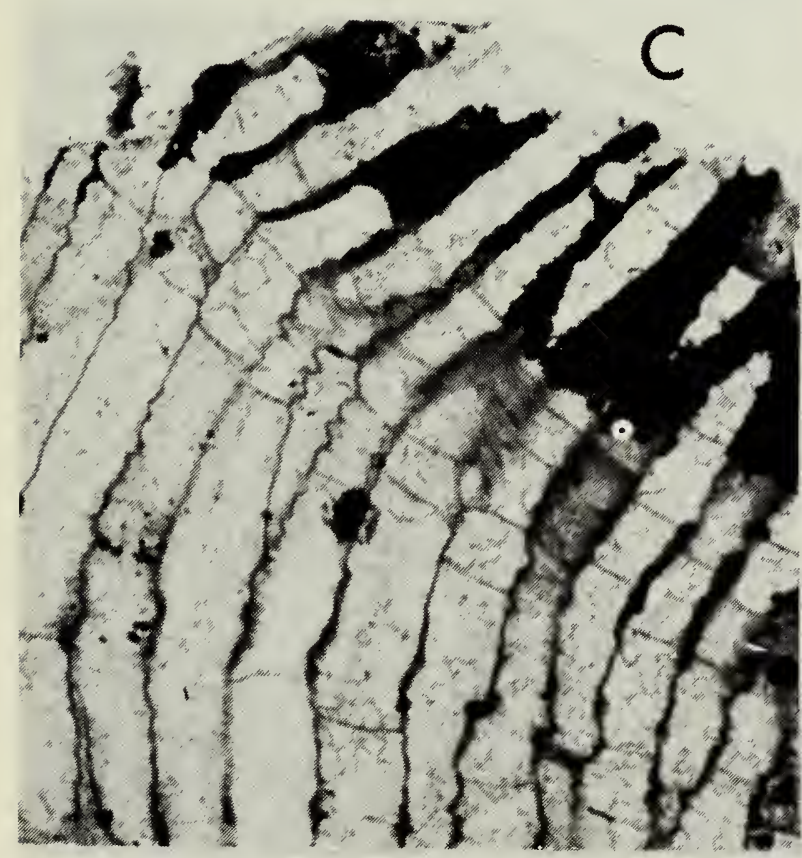

D

5.5.

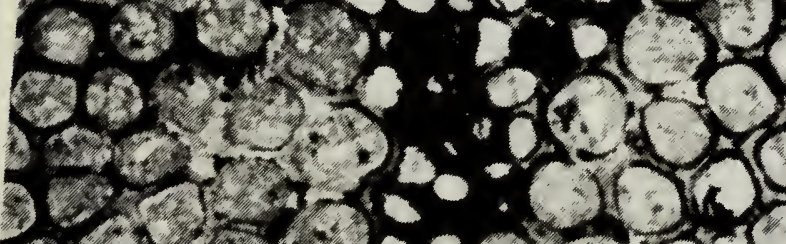

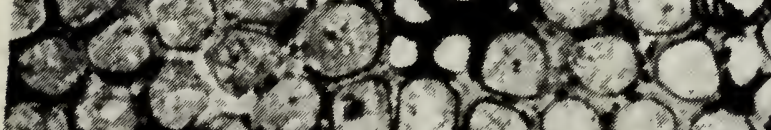
s.o. actort. $3 \mathrm{x}+\mathrm{CO}-4$ $3, x+2001$ $8-12$ a
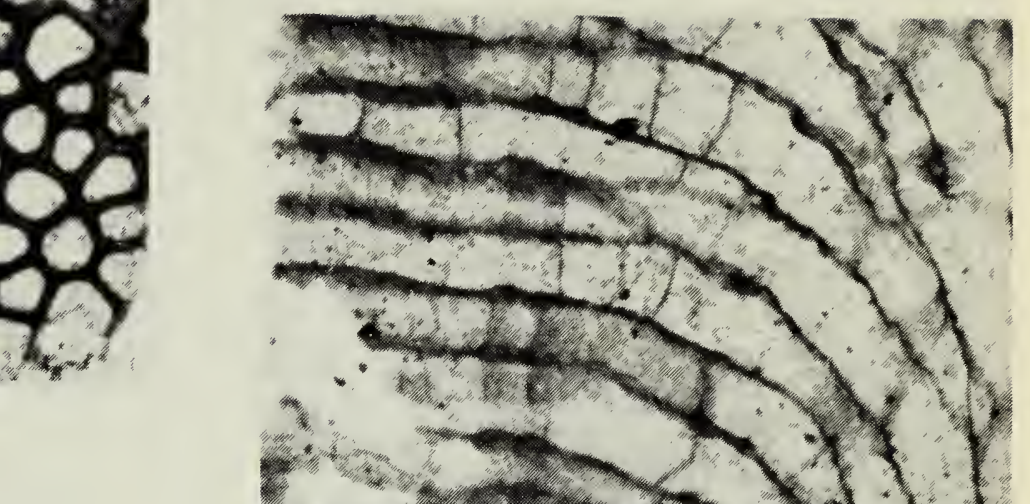
-20 - 5
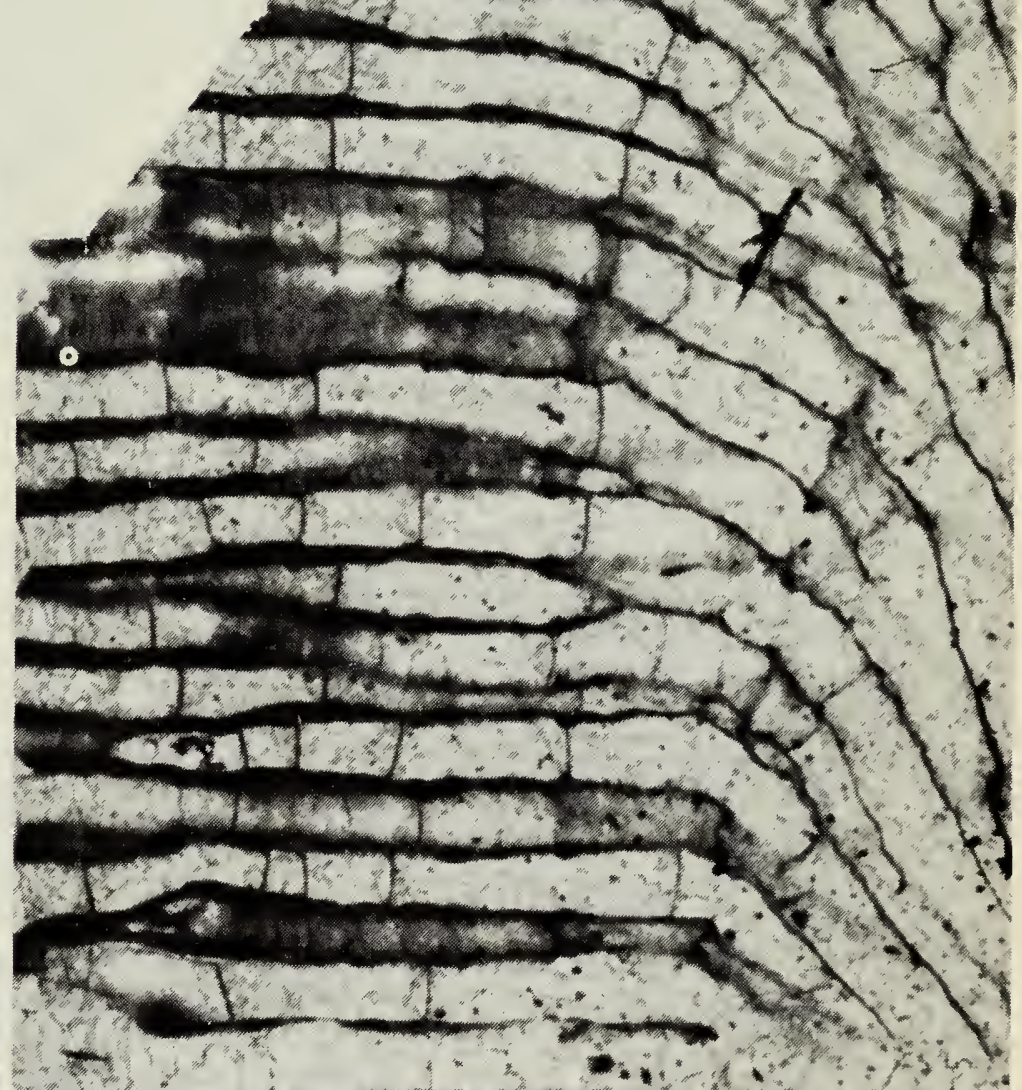

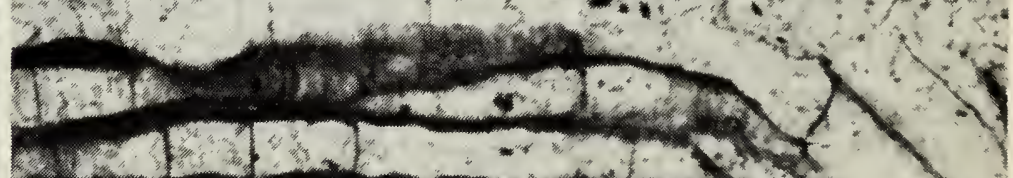

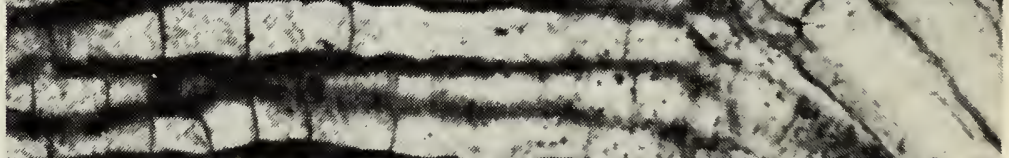

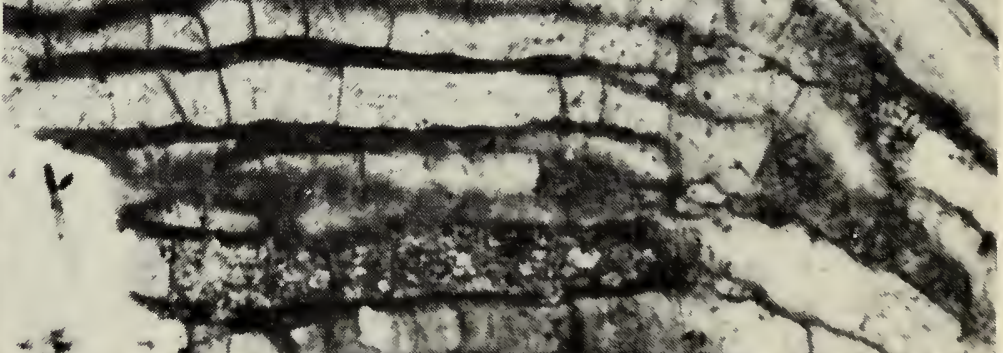

$+$

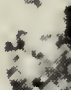

ych

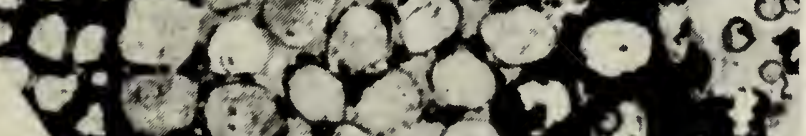
4 C 15 (2)

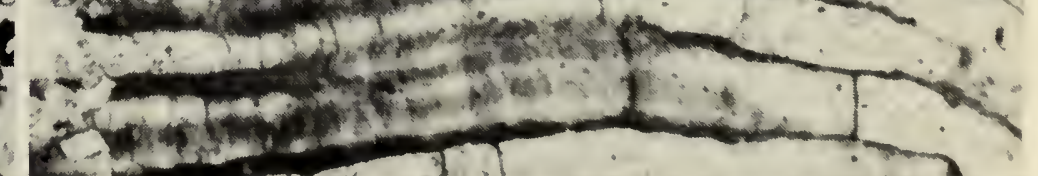


All three species referred to in the foregoing remarks are compared quantitatively in pairs in Table 9, where A represents $H$. meafordensis, B $H$. robusta, and $\mathrm{C} H$. definita. Resulting analysis shows: $\mathrm{A}$ and $\mathrm{B}$ differ significantly in number of zooecia in $2 \mathrm{~mm}$ in intermonticular area, in number of entire mesopores in $1 \mathrm{~mm}^{2}$ in intermonticular area, in number of acanthopores in $1 \mathrm{~mm}^{2}$ in intermonticular area, and in maximum diameter of zooecia in monticules. $\mathrm{A}$ and $\mathrm{C}$ differ significantly in number of zooecia in $2 \mathrm{~mm}$ in intermonticular area, in number of entire mesopores in $1 \mathrm{~mm}^{2}$ in intermonticular area, in number of acanthopores in $1 \mathrm{~mm}^{2}$ in intermonticular area, and in apertural diameter of zooecia in $\mathrm{mm}$ in monticules. $\mathrm{B}$ and $\mathrm{C}$ differ significantly in number of zooecia in $2 \mathrm{~mm}$ in intermonticular area, in number of entire mesopores in $1 \mathrm{~mm}^{2}$ in intermonticular area, and in number of entire acanthopores in $1 \mathrm{~mm}^{2}$ in intermonticular area (Table 9). From materials available for study it is concluded that Dyer's variety represents a distinct species for which I suggest the new name Heterotrypa meafordensis on the grounds that, as shown, the term "parvulipora" is preoccupied.

\section{Locality}

Meaford Formation, Streetsville, Ontario.

\section{Type}

Holotype ROM 12161 . 


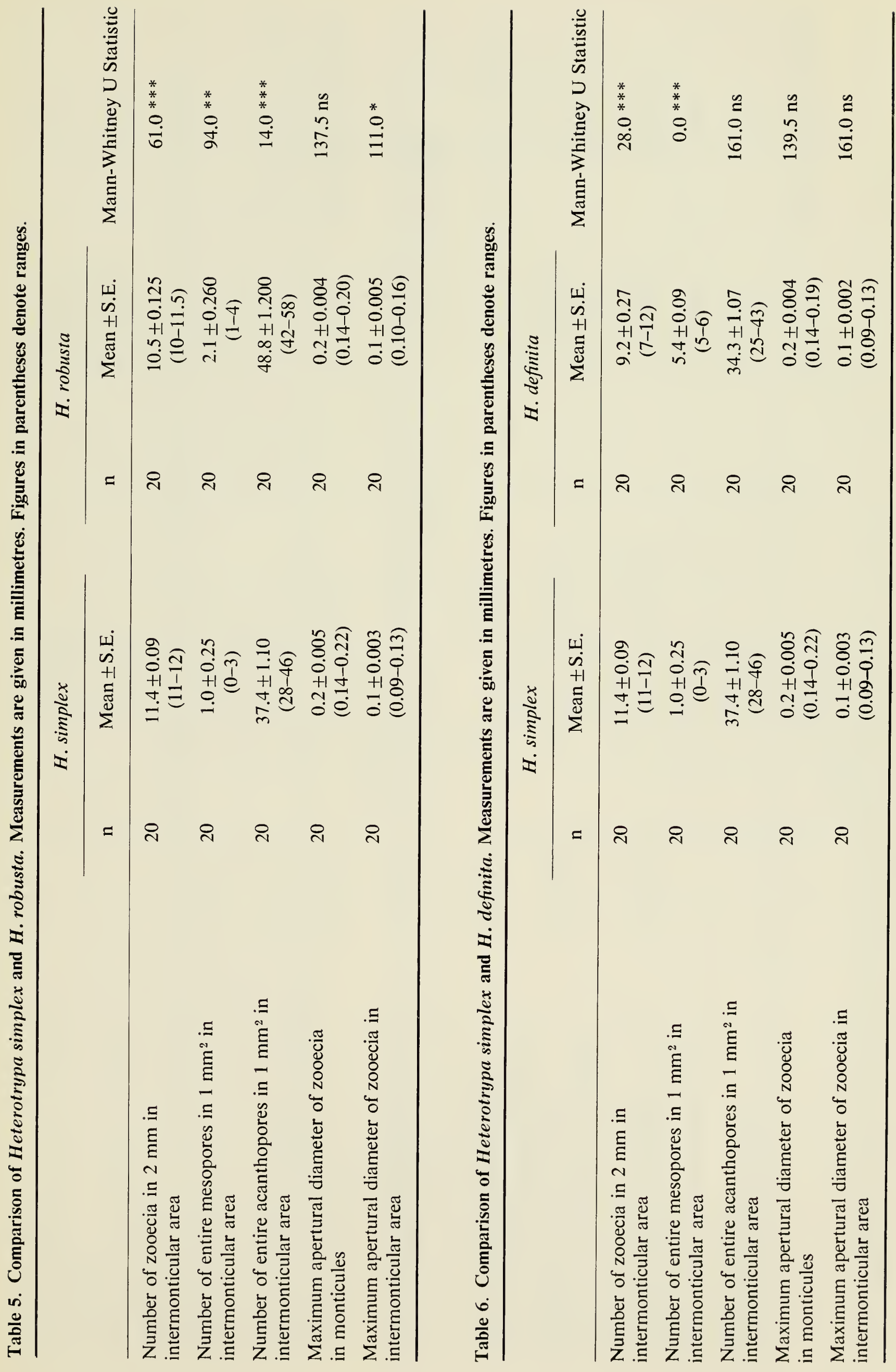




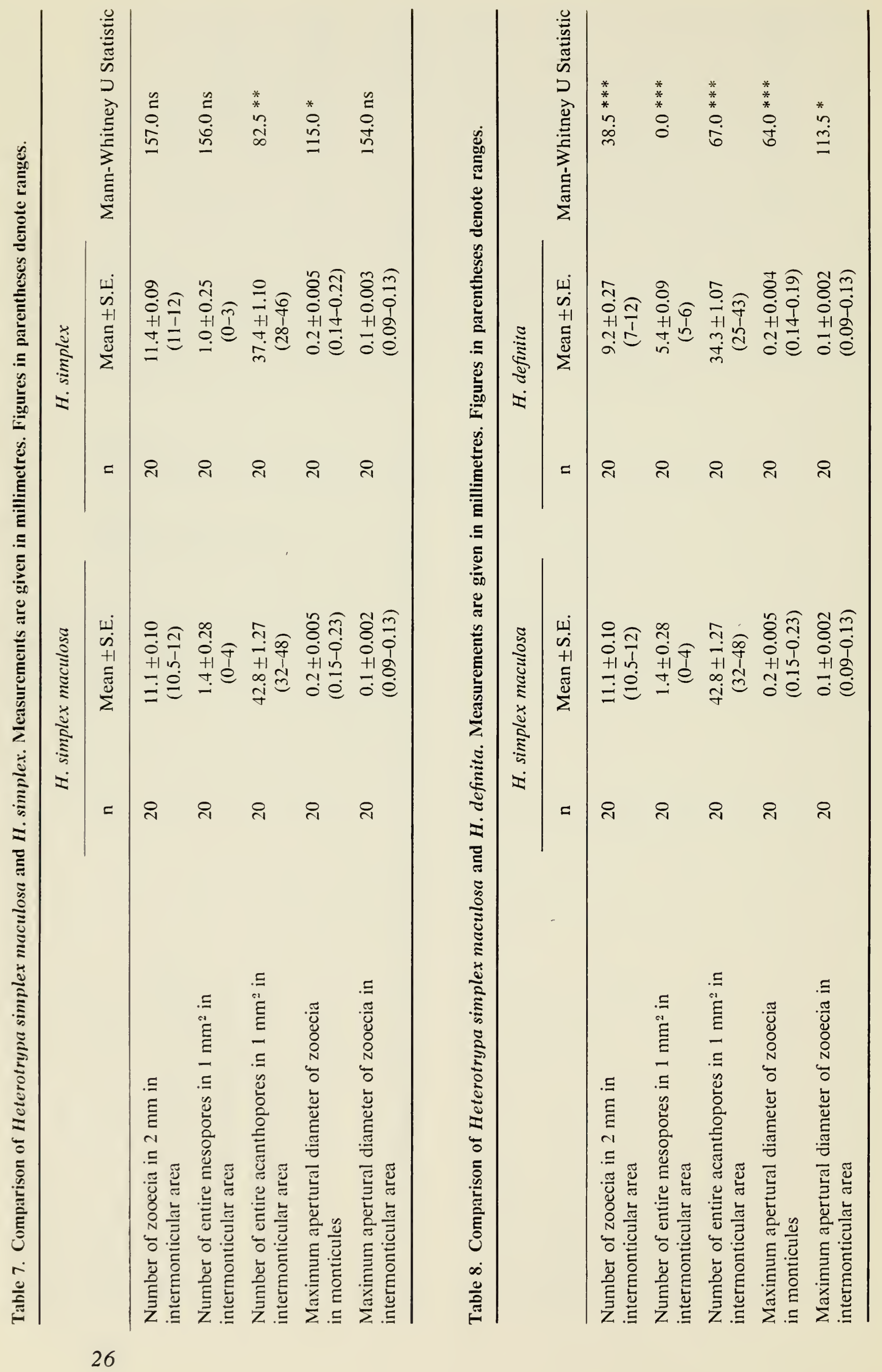




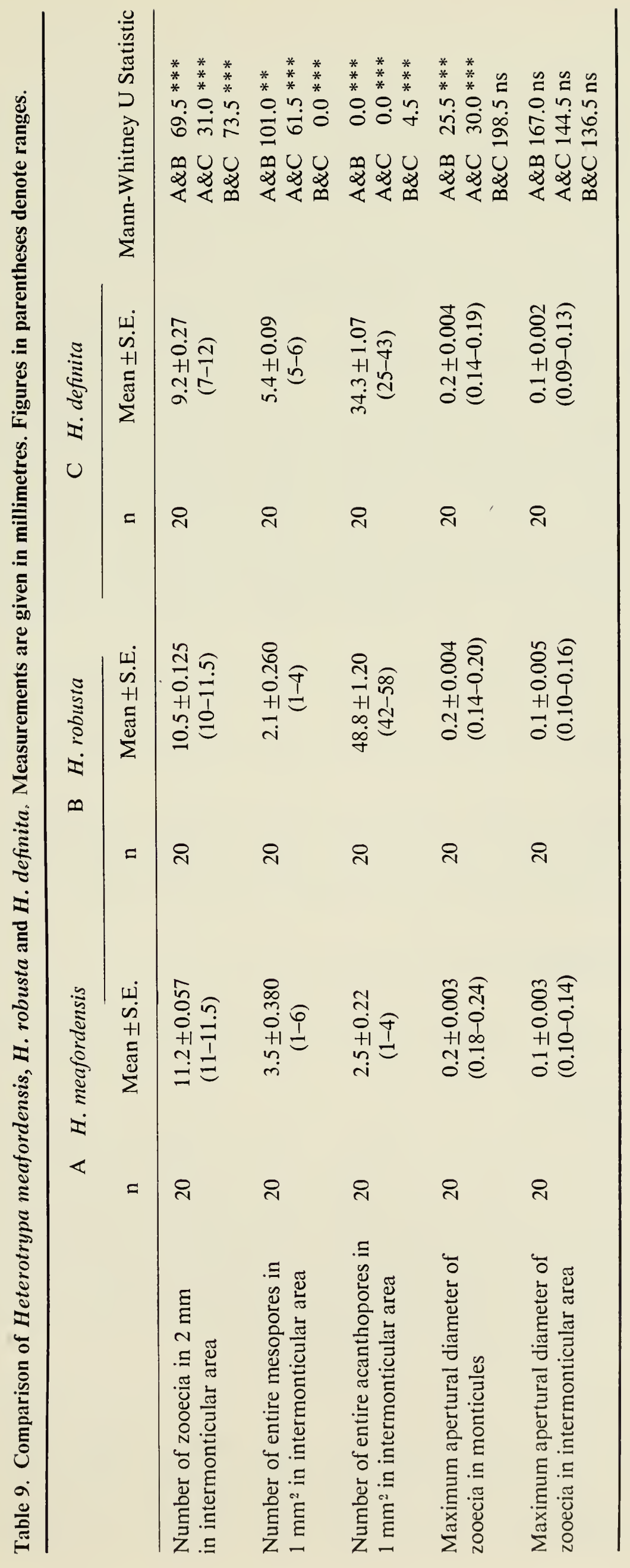




\section{Conclusions}

The striking similarity of the taxa described in this paper affords evidence that the assemblage represents an evolving population in which closely related forms were subjected to successive pressures resulting in minor changes in the skeletal structures. In modern taxonomy they might possibly be regarded as subspecies. Herein, however, they are considered to represent separate species. Heterotrypa simplex maculosa becomes Heterotrypa maculosa and Heterotrypa subpulchella parvulipora is given the new name Heterotrypa meafordensis.

In ROM's Department of Invertebrate Palaeontology, the remaining trepostomatous bryozoan types from the Toronto region belong to the Family Monticuliporidae. Study of remaining types is now in progress. Ultimately I propose to publish separately a table to include data on all the redescribed types in the ROM such as Tables 6 and 7 by Corneliussen and Perry (1973), in which the authors coded the observable characters within a species as present or absent. Several advantages accrue from tables of this sort: e.g., they indicate what characters were sought and this is important in that ideas concerning the taxonomic value of given characters change from time to time. Furthermore, now that numerical taxonomic techniques are commonly employed, the included raw data may serve a useful purpose in future studies.

\section{Acknowledgments}

To Dr. Allan Baker, Assistant Curator, Department of Ornithology, Royal Ontario Museum, I am indebted for his generous assistance in calculating the Mann-Whitney U-tests.

The late Professor T.G. Perry, Indiana University, lent the holotype of Heterotrypa microstigma Cumings and Galloway, IU 4646, 9122-22,23 from the Waynesville (Lower Richmond), Cut 13 on the Big Four Railroad, near Weisburg, Indiana.

Thanks are expressed to Mr. John Monteith, Curatorial Assistant, Department of Invertebrate Palaeontology, ROM, for the restoration of original thin sections and for the preparation of well-oriented new sections necessary for the research, and to Miss Joan Burke for her expert secretarial assistance during the preparation of the text and for the typing of the manuscript.

The photomicrographs were taken by Mr. Brian O'Donovan, Department of Geology, University of Toronto.

Sincere appreciation is expressed to Dr. John Utgaard, Department of Geology, Southern Illinois University, Carbondale, Illinois, and to Dr. Alan Horowitz, Department of Geology, Indiana University, Bloomington, Indiana, who kindly read the manuscript. 


\section{Literature Cited}

ARMSTRONG, H. S.

1945 Stigmatella in the Ordovician of the Central Ontario Basin. J. Paleont., 19(2): 149-157. BOARDMAN, R. S.

1960 Trepostomatous Bryozoa of the Hamilton Group of New York State. Prof. Pap. U.S. Geol. Surv., 340: 1-87.

BOARDMAN, R. S. AND J. UTGAARD

1966 A revision of the Ordovician bryozoan genera Monticulipora, Peronopora, Heterotrypa, and Dekayia. J. Paleont., 40(5): 1082-1108.

CORNELIUSSEN, E. F. AND T. G. PERRY

1973 Monotrypa, Hallopora, Amplexopora and Hennigopora (Ectoprocta) from the Brownsport Formation (Niagaran), western Tennessee. J. Paleont., 47(2): 151-220.

CUMINGS, E. R. AND J. J. GALlOWAY

1913 The stratigraphy and paleontology of the Tanner's Creek section of the Cincinnati series of Indiana. 37th Rep. Indiana Dep. Geol. Nat. Resour., 1912: 353-479.

1915 Studies of the morphology and histology of the Trepostomata or monticuliporoids. Bull. Geol. Soc. Am., 26(3): 349-374.

D'ORBIGNY, A. D.

1849 Prodrome de paléontologie stratigraphique universelle des animaux mollusques \& rayonnés, faisant suite au cours élémentaire de paléontologie et de géologie stratigraphiques. Vol. 1. Paris, V. Masson. 394 pp.

DYER, W. S.

1925 The stratigraphy and paleontology of Toronto and vicinity. Part v. The Paleontology of the Credit River section. Rep. Ont. Dep. Mines, 1923, 32(7): 47-88.

FOERSTE, A. F.

1924 Upper Ordovician faunas of Ontario and Quebec. Mem. Geol. Surv. Brch. Can., 138: $1-255$.

FRITZ, M. A.

1970 Redescription of type specimens of the bryozoan Hallopora from the Upper Ordovician of Toronto Region, Ontario. Proc. Geol. Ass. Can., 21: 15-23.

1971 The trepostomatous bryozoan Stigmatella catenulata diversa Parks and Dyer (1922), a synonym for Mesotrypa diversa (Parks and Dyer). Life Sci. Occ. Pap., R. Ont. Mus., 18: 1-6.

1973 Redescription of type specimens of bryozoan Stigmatella from the Upper Ordovician of the Toronto Region, Ontario. Life Sci. Contr., R. Ont. Mus., 87: 1-31.

INTERNATIONAL COMMISSION ON ZOOLOGICAL NOMENCLATURE

1968 Heterotrypa Nicholson, 1879, and Peronopora Nicholson, 1881 (Bryozoa: designation of type-species under the plenary powers). Bull. Zool. Nom., 24(6): 335-336.

LIBERTY, B. A.

1969 Palaeozoic geology of the Lake Simcoe area, Ontario. Mem. Geol. Surv. Brch. Can., 355: 1-201.

NICHOLSON, H. A.

1875 Corals of the Cincinnati Group. In Description of the corals of the Silurian and Devonian systems. Rep. Geol. Surv. Ohio, 2(2): 183-223.

1879 On the structure and affinities of the "tabulate corals" of the Palaeozoic period, with critical descriptions of illustrative species. Edinburgh, W. Blackwood. 342 pp.

1881 On the structure and affinities of the genus Monticulipora and its sub-genera, with critical descriptions of illustrative species. Edinburgh, W. Blackwood. 240 pp.

PARKS, W. A.

1924 Upper Ordovician at Toronto, Ontario. Bull. Geol. Soc. Am., 35(1): 103-104 [Abstract].

PARKS, W. A. AND W. S. DYER

1922 The stratigraphy and paleontology of Toronto and vicinity. Part II. The Molluscoidea. Rept. Ont. Dep. Mines, 1921, 30(7): 1-59.

SIEGEL, $\mathrm{S}$.

1956 Nonparametric statistics for the behavioral sciences. New York, McGraw-Hill. 312 pp. 
ULRICH, E. O.

1879 Descriptions of a new genus and some new species of bryozoans from the Cincinnati Group. J. Cincinn. Soc. Nat. Hist., 2(3): 119-131.

1882a American Palaeozoic Bryozoa. J. Cincinn. Soc. Nat. Hist., 5(3): 121-175.

1882b American Palaeozoic Bryozoa. J. Cincinn. Soc. Nat. Hist., 5(4): 232-257.

1883 American Palaeozoic Bryozoa. J. Cincinn. Soc. Nat. Hist., 6(2): 148-168.

1890 Part 11. Palaeontology of Illinois. Section vi. Palaeozoic Bryozoa. In Worthen, A. H. Geological Survey of Illinois. Volume 8. Geology and palaeontology. Edited by J. Lindahl. Springfield, Ill., Published by authority of the Legislature of Illinois, pp. 285-677.

1895 On Lower Silurian Bryozoa of Minnesota. Minn. Geol. Nat. Hist. Surv., Final Rep., 3(1): 96-332.

ULRICH, E. O. AND R. S. BASSLER

1904 A Revision of the Paleozoic Bryozoa. Part II. On the genera and species of Trepostomata. Smithson. Misc. Collns., 47: 15-55.

UTGAARD, J. AND R. S. BOARDMAN

1965 Heterotrypa Nicholson, 1879, and Peronopora Nicholson, 1881 (Bryozoa, Trepostomata: proposed designation of a type species in conformity with generally accepted usage. Z.N. (s.) 1693. Bull. Zool. Nom., 22(2): 112-118.

UTGAARD, J. AND T. G. PERRY

1964 Trepostomatous bryozoan fauna of the upper part of the Whitewater Formation (Cincinnatian) of eastern Indiana and western Ohio. Bull. Indiana Dep. Conserv. Geol. Surv., 33: 1-111. 

ISBN 0-88854-169-4 